NBER WORKING PAPER SERIES

\title{
SOCIAL TRUST AND DIFFERENTIAL REACTIONS OF LOCAL AND FOREIGN INVESTORS TO PUBLIC NEWS
}

\author{
Chunxin Jia \\ Yaping Wang \\ Wei Xiong \\ Working Paper 21075 \\ http://www.nber.org/papers/w21075 \\ NATIONAL BUREAU OF ECONOMIC RESEARCH \\ 1050 Massachusetts Avenue \\ Cambridge, MA 02138 \\ April 2015
}

For helpful comments and encouragement, the authors would like to thank Snehal Banerjee, Feng Li, Roger Loh, Christopher Parsons, Jun Qian, Nancy Qian, Paola Sapienza, Andrei Shleifer, Rene Stulz, Luigi Zingales, and seminar participants at American Economic Association Meetings, CKGSB, Hong Kong University, Mitsui Finance Symposium at University of Michigan, NBER Behavioral Finance Meeting, NBER Conference on Chinese Economy, Peking University, SAC, Stanford China Conference, and Tulane. The views expressed herein are those of the authors and do not necessarily reflect the views of the National Bureau of Economic Research.

NBER working papers are circulated for discussion and comment purposes. They have not been peerreviewed or been subject to the review by the NBER Board of Directors that accompanies official NBER publications.

(C) 2015 by Chunxin Jia, Yaping Wang, and Wei Xiong. All rights reserved. Short sections of text, not to exceed two paragraphs, may be quoted without explicit permission provided that full credit, including (C) notice, is given to the source. 
Social Trust and Differential Reactions of Local and Foreign Investors to Public News

Chunxin Jia, Yaping Wang, and Wei Xiong

NBER Working Paper No. 21075

April 2015

JEL No. F3,G02,G14

\section{ABSTRACT}

This paper uses the segmented dual-class shares issued by several dozen Chinese firms---A shares to local Chinese investors and $\mathrm{H}$ shares to foreign investors---to compare reactions of local and foreign investors to the same public news. We find that local investors react more strongly to earnings forecasts by local analysts, while foreign investors react more strongly to forecasts of foreign analysts. This finding highlights social trust as a force driving people with different social backgrounds to react differently to the same information.

Chunxin Jia

Guanghua School of Management

Peking University

Beijing, China

cjia@gsm.pku.edu.cn

Yaping Wang

Guanghua School of Management

Peking University

Beijing, China

ywang@gsm.pku.edu.cn
Wei Xiong

Princeton University

Department of Economics

Bendheim Center for Finance

Princeton, NJ 08450

and NBER

wxiong@princeton.edu 
Information processing is critical to almost all economic decision making. Does the reaction of a decision maker to a piece of information depend on the social trust between the decision maker and the source of the information? This question is motivated by a growing branch of literature in economics and finance that highlights social trust as a key factor in many economic transactions, such as international trades (Guiso, Sapienza, and Zingales, 2009), participation in stock markets (Guiso, Sapienza, and Zingales, 2008), and hiring money managers (Gennaioli, Shleifer, and Vishny, 2013). If social trust affects people's information processing, two reasonable people may react differently to the same piece of public information simply because they have different social and cultural connections to the source of the information. This insight, if it holds true, has implications for many important issues, such as why investors trade so much in financial markets and why investors cannot simply hire foreign advisors to overcome informational barriers they face in investing in foreign assets.

In June 2011, American analysts of Muddy Waters Research and Citron Research released a series of reports on a number of Chinese firms, including Sino Forest Corporation listed on Toronto Stock Exchange and Harbin Electric listed on NASDAQ, accusing them of accounting frauds. These reports had led to not only large stock price crashes of the firms being accused but also substantial price declines of all Chinese stocks listed on NASDAQ by as much as $15 \%$ in June 2011. In sharp contrast to the dramatic reaction of NASDAQ investors, investors inside China hardly reacted to these reports, which were widely circulated by financial news media inside China. Many Chinese investors believed that these overseas analysts were vicious and had exaggerated their cases against the Chinese firms. ${ }^{1}$ As a result, stock prices traded inside China barely budged during this period. This example shows that trust may have an important effect on investors' reactions to public information, even though this example does not permit a statistical comparison of the reactions of NASAQ investors and Chinese investors.

To systematically measure differential reactions of local and foreign investors to the same news, one can compare price reactions of the same set of stocks traded by two groups of

\footnotetext{
${ }^{1}$ Lee, Li and Zhang (2014) systematically examine the financial heath and performance of Chinese reverse merger firms on the U.S. stock markets between 2001 and 2010, the main targets in these accusations, and find that they tend to be more mature and less speculative than either their U.S. counterparts or a group of exchange-industry-size matched firms. As a group, Chinese reverse merger firms outperformed their matched peers from inception through the end of 2013, even after including most of the firms accused of accounting fraud.
} 
investors. Such a comparison is not feasible in typical asset markets whereby investors are mixed together in trading. This paper takes advantage of a unique setting of segmented dual-class shares of a set of Chinese firms. Several dozen Chinese firms have simultaneously listed their shares inside mainland China (i.e., the part of China excluding Hong Kong, Macau and Taiwan) in the Shanghai and Shenzhen Stock Exchanges and outside in the Stock Exchange of Hong Kong (SEHK). While Hong Kong officially returned to China in 1997 from British colonization, it has an autonomous government and a financial system independent of the mainland's. China's capital controls prevent capital from freely moving between the mainland and outside (including Hong Kong), in sharp contrast to the flexibility that allows capital to move freely between Hong Kong and other parts of the world. The capital controls result in segmentation of $\mathrm{A}$ and $\mathrm{H}$ shares and make the SEHK a hub for investment in Chinese stocks by foreign investors. We refer to Ashare investors, who are primarily residents of the mainland, as "local" and H-share investors, who are a balanced mix of investors from Hong Kong and other parts of the world, as "foreign." As the $\mathrm{A}$ and $\mathrm{H}$ shares have the same cash flow and voting rights, their prices separately reflect the beliefs and preferences of the local and foreign investors.

How do local and foreign investors react to the same public information? A naïve benchmark is that local and foreign investors should have the same reaction. However, a common wisdom in the international finance literature is that local investors are better informed than foreign investors about home assets due to their superior private information. As a result, local investors tend to find the same public information about home assets less informative than foreign investors and thus react less strongly. ${ }^{2}$ This information asymmetry theory implies that the reaction of local investors to any public information is weaker. ${ }^{3}$ Consistent with this implication, we also find that in our sample of A and $\mathrm{H}$ pairs, A-share prices react less strongly than H-share prices to firms’ earnings announcements.

\footnotetext{
2 Specifically, Gehrig (1993) and Brennan and Cao (1997) develop two-country noisy rational expectations (NRE) models, in which investors in two countries trade two stocks, one by each country. Investors in both countries receive a signal on the fundamental value of each stock but the signal on the home stock is more precise.

3 Consistent with the information asymmetry theory, the literature has documented that foreign equity flows are positively correlated with home returns (e.g., Bohn and Tesar (1996) and Brennan and Cao (1997)) and display positive feedback to past returns (e.g., Choe, Kho, and Stulz (1999) and Froot, O’Connell, and Seasholes (2001)).
} 
If social trust influences the information processing of local and foreign investors, we expect their reactions to be dependent on their social and cultural connections with the source of information. Local investors may find local analysts, who share a similar cultural and social background, more trustworthy than foreign analysts, who might come from different backgrounds and analyze stocks with different investment philosophies. As a result, local investors find local analysts more trustworthy and their information more informative. Reciprocally, by having better knowledge of the concerns and excitements of local investors, local analysts may also be better at catering toward the sentiment of local investors, which in turn breeds trust of local investors for local analysts. Similarly, foreign investors may find foreign analysts more trustworthy, and reciprocally foreign analysts may also be better at catering toward the sentiment of foreign investors. Taken together, we test whether the likely joint presence of the trust of local (foreign) investors for local (foreign) analysts and the reciprocal catering behavior of local (foreign) analysts to local (foreign) investors symmetrically cause local analysts to be more responsive to information provided by local analysts and foreign analysts to be more responsive to information provided by foreign analysts.

In contrast to the information asymmetry theory, this trust based hypothesis implies that local investors are not necessarily always less responsive to public information and may be more responsive to certain information, and, in particular, information from sources they trust more. In other words, there may be a nuanced pattern in the differential reactions of local and foreign investors, with local investors being more responsive to information from local analysts while foreign investors being more responsive to information from foreign analysts. The focus of our empirical analysis is to test the differential reactions of local and foreign investors to forecasts of local and foreign analysts as implied by this trust based hypothesis.

Specifically, we use an event-study approach to compare daily price reactions of the pairs of A and $\mathrm{H}$ shares to analysts' earnings forecast revisions. From Bloomberg, we collect a large sample of earnings forecasts made by financial analysts of brokerage and research firms inside and outside mainland China (which we call local and foreign houses). As Bloomberg is widely subscribed by financial institutions inside and outside the mainland, analyst forecasts released through Bloomberg are public news to investors of both $\mathrm{A}$ and $\mathrm{H}$ shares. Analysts make a large number of forecasts and, as a result, an average forecast might be noisy and generate no visible 
price reaction. However, as pointed out by Loh and Stulz (2011), a small fraction of the forecasts do offer important information and can lead to significant price reactions. We thus adopt their logit regression approach to examine influential forecast revisions---those that are accompanied by significant abnormal stock returns in the same direction as the revisions---and, specifically, whether forecasts made by local or foreign analysts are more likely to be influential among Ashare or $\mathrm{H}$-share investors.

Consistent with the trust based hypothesis, we find a salient pattern that forecast revisions by analysts of local houses are significantly more likely to be influential among A-share investors while revisions by analysts of foreign houses are significantly more likely to be influential among H-share investors. This symmetric pattern is robust after controlling for a host of analyst, firm, and market characteristics. One cannot explain the symmetric pattern by A-share investors being more informed about the firms, which implies that A-share investors should be less responsive to the forecast revisions of both local and foreign houses. Neither can this pattern be explained by forecasts of local analysts being more or less accurate than that of foreign analysts. As long as both A-share and $\mathrm{H}$-share investors agree on the forecast precision of an analyst (either local or foreign), we expect them to react to the analyst's forecast similarly if they are equally informed by the firm, or $\mathrm{H}$-share investors to always react more strongly if $\mathrm{H}$-share investors are less informed, which is in contrast to our findings of A-share investors reacting more strongly to local analysts and H-share investors reacting more strongly to foreign analysts. This contrast highlights the relevance of the trust effect in explaining the observed differential reactions of A- and $\mathrm{H}$-share investors.

One might further argue that realistic institutional settings can give local investors better access to reports of local houses and foreign investors better access to reports of foreign houses. Local (foreign) houses are more likely to email their reports and make their analysts available to their customers, which are usually local (foreign) institutional investors. While Bloomberg provides the abstract of each analyst report on Chinese firms in both Chinese and English, local houses usually issue reports in Chinese while foreign houses in English. The use of different languages also makes reports of local (foreign) houses more accessible to local (foreign) investors. Furthermore, the differential access may also make local investors more informed 
about the competence of individual analysts of local houses and foreign investors more informed about the competence of individual analysts of foreign houses.

To systematically control for these arguments, we further explore differential reactions of Ashare and H-share prices to different analysts within local and foreign houses. It is common for foreign houses to hire both Chinese and non-Chinese analysts (identified by their last names) to cover Chinese firms. As the reports of Chinese and non-Chinese analysts of a given foreign house are written in the same language and distributed by the same channels of the house, a given investor has the same access to these reports, even if H-share investors may have better access than A-share investors. Interestingly, by separately examining the subsample of forecasts of foreign houses, we find a significant difference-in-difference effect that the stronger reactions of foreign investors relative to local investors are significantly more pronounced to forecasts made by non-Chinese analysts than to forecasts by Chinese analysts. Consistent with the closer social connections between non-Chinese analysts and foreign investors, this difference-indifference effect further supports social trust as a key force in driving the differential reactions of local and foreign investors to analyst forecast revisions.

The local houses typically hire only Chinese analysts, but some of them have been educated inside China and others outside China. By examining the subsample of forecasts of local houses, we find another significant difference-in-difference effect: the stronger reactions of local investors relative to foreign investors are more pronounced to forecasts made by locally educated Chinese analysts than to forecasts by foreign-educated Chinese analysts. To the extent that locally educated analysts are socially more connected to local investors, this effect again supports the trust based hypothesis.

Taken together, our analysis documents a set of patterns in the differential reactions of local and foreign investors to public news. These patterns highlight social trust as an important force driving people with different social backgrounds to react differently to the same information. In interpreting our findings, it is useful to keep in mind that these findings may reflect several channels for social trust to affect investors’ information processing: 1) local (foreign) investors having more trust for local (foreign) analysts, 2) local (foreign) analysts being better at catering 
to local (foreign) investors, and 3) local (foreign) investors paying more attention to the more trustworthy reports of local (foreign) analysts due to their limited attention.

The paper is organized as follows. We discuss the related literature in Section I and describe the institutional setting in Section II. Section III discusses the empirical design. We analyze price reactions of A and $\mathrm{H}$ shares to firms' earnings announcements in Section IV. Section V reports our main results on differential reactions of $\mathrm{A}$ and $\mathrm{H}$ shares to analysts' earnings forecast revisions. Finally, Section VI concludes the paper.

\section{Related Literature}

Besides the aforementioned social trust literature, our finding also adds to the understanding of the heterogeneity between local and foreign investors, which is critical for understanding several central issues in international finance, such as home bias and dynamics of international equity flow. ${ }^{4}$ French and Poterba (1991) and Shiller, Kon-Ya, and Tsutsui (1991) attribute home bias to local investors’ optimism about home equity returns. Dornbusch and Park (1995) and Radelet and Sachs (2000) argue that foreign investors tend to overreact to changes in local fundamentals and the resulting capital inflows and outflows can destabilize local economies. Our analysis highlights social trust as a new factor, in addition to the well-known information asymmetry between local and foreign investors, in determining the optimism of local investors and the over-reactions of foreign investors. By highlighting the role of social trust, our finding also sheds light on why foreign investors cannot simply hire more informed local advisors to overcome informational barriers they face in investing overseas.

By showing that local and foreign investors have different degrees of trust with respect to different sources of public information, our analysis also provides empirical evidence to justify the premise of a strand of theoretical literature that builds on investors agreeing to disagree about the precision of different public information and thus reacting differently, e.g., Harrison and Kreps (1978), Harris and Raviv (1993), Kandel and Pearson (995), Scheinkman and Xiong (2003), Dumas, Kurshev, and Uppal (2009), and Cao and Ou-yang (2009). ${ }^{5}$ In particular, Dumas,

\footnotetext{
${ }^{4}$ See Coeurdacier and Rey (2011) and Lewis (2011) for reviews of the extensive literature related to these issues.

${ }^{5}$ See Hong and Stein (2007) and Xiong (2012) for more detailed reviews of this literature.
} 
Lewis, and Osambela (2011) adopt such a conceptual framework to analyze equilibrium dynamics of international equity flow.

There is extensive empirical literature analyzing price differentials of twin shares and dualclass shares. Froot and Dabora (1999) study stock prices of three pairs of twin corporations whose charters fix the division of current and future cash flows between two twin companies, and highlight market-sentiment shocks as an explanation of persistent and substantial price deviations between these twin shares. Stulz and Wasserfallen (1993) and Bailey and Jagtiani (1994) examine price deviations of dual-class shares issued by Swiss and Thai firms to local and foreign investors, and emphasize differences between the risk exposures of local and foreign investors as a key driver of the price deviations. Several prior studies, e.g., Fernald and Rogers (2002), Chen and Xiong (2002), Karolyi and Li (2003), Chan, Menkveld, and Yang (2008), and Mei, Scheinkman, and Xiong (2009), have also examined the substantial price deviations between different classes of shares issued by Chinese firms to local and foreign investors. These studies attribute the price deviations to differences in investment opportunity sets, liquidity, and speculative trading motives of local and foreign investors. In contrast to all of these studies, which are primarily concerned with the differences in price levels of twin shares and dual-class shares, we use an event-study approach to compare daily price reactions of $\mathrm{A}$ and $\mathrm{H}$ shares to public news, which allows us to analyze reactions of local and foreign investors to the same public information. In this regard, our analysis also differs from the literature on the improved information environment of individual stocks induced by cross listing, e.g., Baker et al. (2002), Lang et al. (2003), and Bailey, Karolyi, and Salva (2006).

Our analysis also differs in emphasis from the literature that highlights proximity as an important determinant of the accuracy of analyst forecasts. Bae, Stulz and Tan (2008) find that analysts resident in a country make more precise earnings forecasts for firms in that country than analysts who are not resident in that country. Furthermore, Du, Yu and Yu (2014) find that among U.S. analysts who cover Chinese firms listed in the U.S. stock markets, analysts with Chinese ethnic origin provide more accurate forecasts than analysts without Chinese origin. In contrast, our analysis compares the reactions of local and foreign investors to a given forecast, either by Chinese or non-Chinese analysts. 
Another branch of the literature analyzes factors that determine investors' portfolio holdings of foreign assets (i.e., home bias). Grinblatt and Keloharju (2001) emphasize the key role of distance, language and cultural similarities in international asset allocation. Portes and Rey (2005) show that physical distance significantly affects international equity flows and holdings. Chan, Covrig, and Ng (2005) find that stock market developments and familiarity variables have a significant impact on home bias. Like these studies, our analysis also confirms information frictions and social factors as important factors in explaining the heterogeneity between asset valuations of local and foreign investors. Different from these studies, which are mostly concerned with the level of foreign portfolio holdings, our focus on comparing local and foreign investors' daily reactions to public news allows us to closely analyze the effect of social trust on local and foreign investors' information processing.

\section{Segmented Pairs of $\mathbf{A}$ and $\mathbf{H}$ Shares}

\section{A. Institutional Background}

China established the Shanghai Stock Exchange and the Shenzhen Stock Exchange in 1990 and 1991, respectively, to list stocks issued by Chinese firms. Since then, the Chinese stock markets have rapidly grown. By the end of 2011, these two stock exchanges listed the stocks of 2342 firms, with a total market value of 21,475.81 billion RMB (3,408.37 billion U.S. dollars), which represented 46\% of China's 2011 GDP. There are two types of shares: A shares, which are traded in Chinese RMB, and B shares, which are traded in U.S. dollars in the Shanghai Stock Exchange and in Hong Kong dollars in the Shenzhen Stock Exchange, respectively. ${ }^{6}$ The vast majority of firms issue A shares. At the end of 2011, 2320 out of 2342 firms issued A shares and only 108 issued B shares. ${ }^{7}$

Many Chinese firms have also chosen to list their stocks outside mainland China, in places such as Hong Kong, New York, Singapore, and London. Due to its geographical proximity to the mainland, the Stock Exchange of Hong Kong (SEHK) is often the first choice when a

\footnotetext{
${ }^{6}$ Before February 2001, A shares were restricted to Chinese residents while B shares were restricted to foreign investors. After February 2001, the Chinese government relaxed the restriction on B shares by allowing Chinese residents with foreign currency to legally own and trade B shares, while maintaining the restriction on A shares.

${ }^{7}$ Some firms issue both A and B shares.
} 
Chinese firm decides to list overseas. Shares issued by Chinese firms in the SEHK are often called H shares. H shares were first listed by a Chinese firm in 1993. By the end of 2011, 167 Chinese firms had listed their $\mathrm{H}$ shares, with a total market value of 4107.27 billion Hong Kong dollars, accounting for $23.38 \%$ of the market capitalization of the SEHK.

Interestingly, a set of firms issued both $\mathrm{A}$ and $\mathrm{H}$ shares. These dually listed shares are the main sample of our analysis. A and $\mathrm{H}$ shares of these firms offer the same voting and cash-flow rights. The three stock exchanges involved in listing these shares all require the firms to disclose identical information to investors, including those inside and outside mainland China.

China imposes capital controls, which prevent local and foreign investors from freely moving capital across its borders. As a result, local investors cannot simply move capital to Hong Kong to trade $\mathrm{H}$ shares; neither can foreign investors move capital to the mainland to trade A shares. China's capital controls thus lead to segmentation of A and H shares. ${ }^{8}$ Due to this segmentation, it is difficult for people to arbitrage any price deviation between the $\mathrm{A}$ and $\mathrm{H}$ shares issued by the same firm. Instead, the prices of $\mathrm{A}$ and $\mathrm{H}$ shares reflect risk preferences and beliefs of two groups of investors inside and outside mainland China.

Investors inside mainland China are predominantly local individuals or institutions. In contrast, investors in the SEHK come from all over the world. Based on the survey data released by Hong Kong Exchange Clearing Limited (HKEx), ${ }^{9}$ which owns the SEHK, during the 12month period from October 2010 to September 2011, investors from Hong Kong contributed to only $42 \%$ of the SEHK's total trading volume, among which $20 \%$ was from institutional investors and $22 \%$ was from retail investors, while investors from outside Hong Kong contributed to $46 \%$ of the trading volume, among which $42 \%$ was from institutional investors

\footnotetext{
${ }^{8}$ There are two exceptions to the capital controls. In 2002, China introduced a program called Qualified Foreign Institutional Investors (QFIIs), which allowed a selected group of foreign institutions to invest in financial assets inside mainland China subject to quotas set by the China Securities Regulatory Commission (CSRC). By the end of 2011, there were 135 QFIIs, with a total investment quota up to 1.64 billion U.S. dollars, which was minor relative to the market capitalization of China's stock markets. In 2007, China launched another program called Qualified Domestic Institutional Investors (QDIIs), which allowed a group of domestic institutions to invest in securities outside mainland China, including stocks traded in Hong Kong, again subject to quotas set by the CSRC. By the end of 2011, 32 asset management firms and 10 securities firms were granted the QDII status, with a total investment value of merely 58.2 billion RMB invested outside of mainland China.

${ }^{9}$ See the website of HKEx at http://www.hkex.com.hk/eng/stat/statrpt/factbook/factbook2011/Documents/32.pdf.
} 
and $4 \%$ was from retail investors. ${ }^{10}$ Within the trading volume by overseas investors, the fractions of investors from the U.S., the U.K., continental Europe, and mainland China were 28\%, $27 \%, 14 \%$, and $10 \%$, respectively. ${ }^{11}$ The relatively minor contribution of mainland China investors reflects China's restrictive capital controls that prevent its residents from trading shares listed in Hong Kong.

It is useful to note that while the residents of Hong Kong all speak Cantonese (a dialect of Chinese), 150 years of British rule with English as the official language and a different education curriculum from mainland China had caused a substantial gap between mainland Chinese and Hong Kong residents in their respective culture and social norms. Hong Kong residents may not fully comprehend the classic Chinese phrases, which are commonly used by mainland Chinese, while mainland Chinese may not share the more westernized investment philosophy of Hong Kong residents. This difference, together with the heavy presence of western investors in the Hong Kong stock markets, motivates us to treat investors in the A-share markets as a separate social group from those in the H-share markets.

\section{B. Summary Statistics}

Our data sample spans January 1, 2006 to April 30, 2012. Our sample starts in 2006 because Bloomberg starts to cover forecasts made by Chinese analysts mostly after 2006. We obtain daily closing stock prices of the pairs of $\mathrm{A}$ and $\mathrm{H}$ shares from CSMAR (for A shares) and RESSET (for $\mathrm{H}$ shares). Figure 1 shows that the number of pairs of $\mathrm{A}$ and $\mathrm{H}$ shares increased over time from 30 at the beginning of our sample on January 1, 2006 to 71 on April 30, 2012. There was no delisting of any $\mathrm{A}$ or $\mathrm{H}$ share in this sample during this period. ${ }^{12}$

\footnotetext{
${ }^{10}$ The remaining $12 \%$ of the trading volume was by dealers.

${ }^{11}$ Beyond the investment flows to $\mathrm{H}$ shares via the QDII program, Hong Kong also hosts a group of mainland residents who regularly travel to Hong Kong for business and other purposes and who are thus able to invest in $\mathrm{H}$ shares.

${ }^{12}$ On April 30, 2012, the actual number of A and H pairs is 72. We have to drop one of the pairs, Xinhua Insurance, because it was listed only at the end of 2011. Among the 72 A and H pairs, 12 listed their A shares on the Shenzhen Stock Exchange and 60 on the Shanghai Stock Exchange. Furthermore, 55 of them had their $\mathrm{H}$ shares listed before their A shares, 9 had A shares listed before the H shares, and only 8 had the IPOs of their A and $\mathrm{H}$ shares at the same time.
} 
The firms that issued these pairs of A and $\mathrm{H}$ shares are typically blue-chip companies from key industries of China, such as energy, electric power, manufacturing, banking, and finance industries. The list of companies includes Industrial and Commercial Bank of China, China Construction Bank, Bank of China, and Agricultural Bank of China (the four largest banks), China Life and Ping An Insurance (the two largest insurance companies), Petro China and Sinopec (the two largest energy companies), and Air China (the largest airline).

The prices of $\mathrm{A}$ and $\mathrm{H}$ shares in these pairs can substantially deviate from each other. Figure 1 also plots the average price ratio of $A$ shares to $H$ shares, value weighted across all available pairs. The average price ratio mostly stayed in a range between 1 and 2 during our sample time. The large price deviations between $\mathrm{A}$ and $\mathrm{H}$ shares confirm the segmentation of $\mathrm{A}$ and $\mathrm{H}$ markets. The literature, as referenced in the Introduction, has pointed out that many factors, such as differences in investment opportunity sets, risk exposure, risk preferences, and sentiment of the A-share and H-share investors, might have contributed to these price deviations. Our study focuses on the differential reactions of $\mathrm{A}$ and $\mathrm{H}$ shares to public news announcements rather than the differences in their price levels.

Table 1 reports the summary statistics of the pairs of $\mathrm{A}$ and $\mathrm{H}$ shares. There are several notable points. First, the returns of A shares, which are measured as the close-to-close returns between two days with valid trading in both $\mathrm{A}$ and $\mathrm{H}$ shares, are significantly less volatile than those of the corresponding $\mathrm{H}$ shares. The average daily return volatility of $\mathrm{A}$ shares is $2.9 \%$ while that of the $\mathrm{H}$ shares is $3.6 \%$. After using a market model to remove the market fluctuations of the Shanghai Composite Index and the Hong Kong Hang Seng Index (widely used indices for Chinese A-share markets and Hong Kong stock markets) from the daily returns of A and $\mathrm{H}$ shares, A shares have an average idiosyncratic volatility of $2.0 \%$ while $\mathrm{H}$ shares have $2.9 \%{ }^{13}$ Second, both A- and H-share returns have positive skewness, and the skewness of $\mathrm{H}$ shares is significantly larger than that of A shares. Third, A shares are more liquid based on two measures of liquidity: turnover rate and the illiquidity measure of Amihud (2002), which is given by absolute value of daily return divided by daily trading volume. Fourth, the fraction of tradable shares held by retail investors is about $58 \%$ in both A-share and H-share markets. Finally, $\mathrm{H}$

\footnotetext{
${ }^{13}$ The higher volatility of $\mathrm{H}$ shares is consistent with $\mathrm{H}$-share investors being potentially less informed about Chinese firms and consequently having more volatile belief fluctuations than A-share investors.
} 
shares have a higher average daily return than A shares even though the average return of the Chinese A-share market index is similar to that of the Hong Kong market index.

Panel B of Table 1 also shows that there are roughly the same number of tradable $\mathrm{A}$ and $\mathrm{H}$ shares in these pairs, with tradable $\mathrm{H}$ shares on average contributing to $51.3 \%$ of the total number of tradable $\mathrm{A}$ and $\mathrm{H}$ shares across all pairs. The daily returns of the pairs of $\mathrm{A}$ and $\mathrm{H}$ shares have only a modest average correlation of 0.444 .

In Panel C of Table 1, we also report the lead-lag relation between the daily returns of $\mathrm{A}$ and H shares. Among the 71 firms in our sample, 36 firms have no Granger causality in either direction, 11 firms have A-share returns Granger causing H-share returns, 14 firms have H-share returns Granger causing A-share returns, and 10 firms have Granger causality in both directions. If we interpret Granger causality as a reflection of the direction of information flow, this panel shows that information flows symmetrically between A shares and H shares.

\section{Empirical Design}

The segmented pairs of $\mathrm{A}$ and $\mathrm{H}$ shares offer a unique opportunity to analyze how investors inside and outside mainland China react to public news about the same firms. We employ two types of regular news events: firms’ annual earnings announcements and financial analysts’ earnings forecast revisions. These events are important sources of information for investors. As the information transmitted by these events is firm specific, it has minimal implications for investors' aggregate wealth and consumption. ${ }^{14}$ That is, it does not affect the discount rates of Ashare and H-share investors.

As A-share and H-share investors face different investment opportunities and market risks, it is likely that they use different discount rates to evaluate the same stock investment and that the difference in their discount rates is an important factor driving the aforementioned large price

\footnotetext{
${ }^{14}$ As the firms in our sample are mostly blue-chip companies from key industries of China, one might argue that news about their earnings might have implications for the overall Chinese economy. We have systematically compared the price volatility of the Chinese stock market index (the Shanghai Composite Index) during the earning announcement period of each firm (from one day before to one day after the announcement) with that outside the announcement period. We find the market volatility is virtually the same. This confirms that news about each firm's earnings is idiosyncratic.
} 
deviations between the pairs of $\mathrm{A}$ and $\mathrm{H}$ shares. By comparing price reactions of $\mathrm{A}$ and $\mathrm{H}$ shares to firm-specific news announcements, we isolate the heterogeneity in the discount rates of Ashare and $\mathrm{H}$-share investors from our analysis of the belief revisions induced by the news among the two groups. Furthermore, we ignore the heterogeneity within each of these groups by treating both A-share and $\mathrm{H}$-share investors as homogenous groups.

The main focus of our analysis is to examine whether social trust affects the information processing of A-share and $\mathrm{H}$-share investors. There is a quickly growing branch of literature that emphasizes social trust as an important factor in many economic transactions. Guiso, Sapienza, and Zingales $(2008,2009)$ argue that cultural and social factors determine the level of trust between people and that trust is an important factor in driving trades between countries and in determining individuals' participation in stock markets. Gennaioli, Shleifer, and Vishny (2013) highlight trust rather than the pursuit of the highest return as the key determinant of people's choices of money managers. It is easy to argue that there are closer social and cultural connections between local investors and local analysts as they share similar social values and use similar jargon. As a result, we hypothesize that local investors trust local analysts more and thus put greater weight on information provided by local analysts relative to foreign investors, who tend to have less social and cultural connections to local analysts. Symmetrically, we hypothesize that foreign investors trust foreign analysts more and thus put a greater weight on information provided by foreign analysts.

Reciprocally, with better knowledge of the sentiment of local investors, local analysts may also have an advantage relative to foreign analysts in catering to local investors. That is, local analysts may be better at relating their reports to particular concerns and excitements of local investors about a firm. As pointed out by the recent literature on media bias, e.g., Mullainathan and Shleifer (2005) and Gentzkow and Shapiro (2006), slanting its reports toward the prior beliefs of its customers help build rather than destroy a media firm's reputation of quality. The same insight may also work for financial analysts. That is, the possible catering behavior of local analysts to local investors' sentiment helps breed trust of local investors for local analysts. Similarly, the possible catering behavior of foreign analysts to foreign investors' sentiment helps breed trust of foreign investors for foreign analysts. As the reciprocal catering behavior of analysts and the trust of one group of investors for one group of analysts are two sides of the 
same coin, we make no attempt to separate these two sides, and instead call them jointly as the trust effect.

Another realistic complication of our analysis is investors' limited attention. As highlighted by the recent finance and economics literature, e.g., Sims (2002), Hirshleifer and Teoh (2004), Peng and Xiong (2006), and Van Nieuwerburg and Veldkamp (2009), investors are unable to process all publicly available information and have to be selective about which information they process. Then social trust is likely to cause local investors to pay more attention to information provided by the more trustworthy local analysts and foreign investors to pay more attention to information provided by foreign analysts. In this way, limited attention exacerbates the effects of social trust. In our analysis, we do not aim to separate this amplification effect of investors' attention constraints from the effect of social trust.

Taken together, we summarize our earlier discussion as the empirical hypothesis below:

The Trust-Based Hypothesis: Local investors put greater weight on public information provided by local analysts, while foreign investors put greater weight on public information provided by foreign analysts.

In testing this hypothesis, we focus on comparing the price reactions of $\mathrm{A}$ shares and $\mathrm{H}$ shares to analysts' earnings forecast revisions. Due to the aforementioned segmentation of Ashare and H-share markets, it is natural to interpret A-shares investors as local investors and $\mathrm{H}$ share investors as foreign investors. The classification of local and foreign analysts is more subtle. At a granular level, we treat local analysts as analysts working for brokerage and research firms inside mainland China (which we call local houses) and foreign analysts as those working for brokerage and research firms outside mainland China (which we call foreign houses). Then, as a first step to test the hypothesis, we compare the price reactions of A shares and $\mathrm{H}$ shares to earnings forecast revisions made by analysts working for local and foreign houses.

It is important to note the heterogeneity within analysts working for local and foreign houses. In particular, it is common for foreign houses to hire both Chinese and non-Chinese analysts to cover stocks of Chinese firms. One could naturally argue that the social distance between $\mathrm{H}$ share investors and non-Chinese analysts is closer than that between H-share investors and 
Chinese analysts. Thus, after controlling for other things, we expect a difference-in-difference effect that the stronger price reactions of $\mathrm{H}$ shares to earnings forecast revisions of foreign houses relative to that of A shares are more pronounced in the subsample of non-Chinese analysts than in the subsample of Chinese analysts.

Furthermore, while local houses typically hire only Chinese analysts to cover Chinese firms, some of the analysts are educated inside mainland China while the others are educated outside. To the extent that analysts educated outside mainland China are more familiar with the culture and investment philosophy outside China, their social distance to H-share investors is closer than that of analysts educated inside mainland China. Thus, after controlling for other things, we expect another difference-in-difference effect that the stronger price reactions of A shares to earnings forecast revisions of local houses relative to that of $\mathrm{H}$ shares are more pronounced in the subsample of analysts educated inside mainland China than in the subsample of analysts educated outside mainland China.

These two difference-in-difference effects allow us to control for a differential access concern. One might argue that A-share investors and $\mathrm{H}$-share investors have different access to analyst reports of different houses. In particular, even though we have restricted our sample to analyst reports available on Bloomberg, it is still possible that A-share investors have better access to analyst reports of local houses while $\mathrm{H}$-share investors have better access to analyst reports of foreign houses. This is because local houses are more likely to directly email their reports to their customers, which are mostly institutional investors inside China, and make their analysts more available to answer questions from their customers. While Bloomberg provides the abstract of each analysts report on Chinese firms in both Chinese and English, local houses usually issue reports in Chinese while foreign houses in English. The use of different languages also makes reports of local (foreign) analysts more accessible to local (foreign) investors. We can directly control for the differential access of local (foreign) investors to the reports of one house by examining their differential reactions to subsamples of reports provides by the same house. For example, in analyzing the sample of earnings forecast revisions by analysts of foreign houses, the reports of Chinese and non-Chinese analysts are written in the same language and distributed by the same channels of their houses. Thus, the differential price reactions of $\mathrm{A}$ and $\mathrm{H}$ shares have to be driven by the difference in how A-share and H-share investors interpret the 
forecasts of Chinese and non-Chinese analysts, rather than the difference in accessing the forecasts.

One may argue that the forecasts made by local analysts might be more accurate than that by foreign analysts, as suggested by the finding of Bae, Stulz and Tan (2008). It is useful to note that if A-share and $\mathrm{H}$-share investors agree on the relative precision of forecasts made by local and foreign analysts and if A-share and H-share investors are equally informed about these firms, they should have the same reactions to the same forecast and react more strongly to the forecasts made by local analysts than that by foreign analysts. Note that this implication is in contrast to the pattern implied by the trust-based hypothesis. Nevertheless, we will explicitly compare the accuracy of forecast accuracy of local and foreign analysts in Section V.E.

Furthermore, one may also argue that local investors are more informed about the competence of individual analysts of local houses and that foreign investors are more informed about the competence of individual analysts of foreign houses. A unique feature of our sample is that A-share and H-share investors observe not only each analyst report but also the price reactions of both $\mathrm{A}$ and $\mathrm{H}$ shares to the report. That is, even if $\mathrm{H}$-share investors are not sure of the quality of a report issued by a local analyst, they can nevertheless infer its quality from the price reaction of A-share investors. Thus, if H-share investors choose not to react to the report despite a strong reaction of A-share investors, the differential reactions reflect the lack of trust of H-share investors for local analysts rather than just their unfamiliarity with the competence of local analysts.

While the main focus of our analysis is to examine the trust-based hypothesis, we also note another important effect caused by local investors being potentially better informed about home firms than foreign investors. As highlighted by the theoretical models of Gehrig (1993) and Brennan and Cao (1997), local investors face less uncertainty about home firms' fundamental values, which, in turn, implies that they react less strongly to any public news than foreign investors. This effect of information asymmetry is likely to work in the background in our analysis of price reactions to analysts' earnings forecast revisions and interfere with our test of the trust effect. Specifically, the effect of information asymmetry works against finding local 
investors reacting more strongly to information from local analysts, but makes it easier to find foreign investors reacting more strongly to information from foreign analysts.

\section{Price Reactions to Earnings Announcements}

In this section, we examine how A-share and H-share prices react to firms' earnings announcements. This analysis serves as a contrast for our main analysis of the price reactions to analysts' forecast revisions of firms' earnings. As firms have to follow standard accounting rules to report their earnings, the information contained in earnings announcements are more objective than that in analyst reports and is thus less susceptible to the trust effect. Thus, the differential price reactions of $\mathrm{A}$ and $\mathrm{H}$ shares to earnings announcements is more likely to reflect the effect of information asymmetry between local and foreign investors. ${ }^{15}$

We focus on each firm's annual rather than quarterly earnings announcements because the Listing Rules of both the Shanghai and Shenzhen Stock Exchanges only require the annual earnings reports of publicly listed firms to be audited by certified auditors. ${ }^{16}$ Consequently, annual earnings reports are more reliable than quarterly earnings reports.

\section{A. Earnings Data}

A firm announces its earnings for both $\mathrm{A}$ and $\mathrm{H}$ shares on the same day. Note that $\mathrm{A}$ and $\mathrm{H}$ shares are subject to accounting standards in mainland China and Hong Kong. These two systems have minor differences in cost and revenue recognition. Despite the different standards, the difference between A-share and $\mathrm{H}$-share earnings is negligible. For convenience, we use $\mathrm{H}$ share earnings in our analysis of price reactions of $\mathrm{A}$ and $\mathrm{H}$ shares. For the 71 firms in our sample, we obtain their reported annual earnings for $\mathrm{H}$ shares, announcement dates, and the consensus of analysts' earnings forecasts one day before each announcement from Thomson One. From 2006 to 2011, there were 249 valid announcements, with both reported earnings and

\footnotetext{
${ }^{15}$ One may still argue that in the presence of possible earnings fraud, social trust may still affect the reactions of foreign and local investors to earnings announcements, and in particular makes foreign investors more concerned with the quality of the announced earnings. This effect works against finding $\mathrm{H}$ shares reacting more strongly to earnings news, as suggested by the information asymmetry theory.

${ }^{16}$ See Section 6.5 of Listing Rules of the Shanghai Stock Exchange and the same section of Listing Rules of the Shenzhen Stock Exchange.
} 
consensus forecasts and sufficient stock return observations for both $\mathrm{A}$ and $\mathrm{H}$ shares around each announcement for an event study.

Table 2 compares the earnings reported for A and H shares. For 245 of the 249 earnings announcements in our sample, Thomson One also provides reported EPS of A shares and $\mathrm{H}$ shares. Among these 245 pairs of EPS for A and H shares, 206 are identical, 15 have only slight differences less than 0.01 RMB, 27 have differences between 0.01 and $0.1 \mathrm{RMB}$, and only 1 has difference larger than $0.1 \mathrm{RMB}$, which is $0.15 \mathrm{RMB}$. If we scale the difference by the previousyear-end $\mathrm{H}$-share price, there are only 6 differences large than 1\%, with a maximum of 5.2\%. The changes in earnings are perhaps more relevant than the levels in terms of information flow. The difference between year-to-year EPS change of $\mathrm{A}$ and $\mathrm{H}$ shares is also small with the correlation between the two changes being 0.999. Taken together, it is reasonable to ignore the difference between the earnings of $\mathrm{A}$ and $\mathrm{H}$ shares induced by accounting standards of $\mathrm{A}$ and $\mathrm{H}$ markets.

We compare a firm's reported earnings per share (EPS) with the consensus of analysts' earnings forecasts before the announcement. We define Surprise---the surprise in the earnings announcement---by the difference between the reported EPS and the consensus of analysts' forecasts deflated by the firm's $\mathrm{H}$ share price at the end of the previous year. ${ }^{17}$

\section{B. Empirical Results}

We first compare the absolute values of cumulative abnormal returns of $\mathrm{A}$ shares and $\mathrm{H}$ shares across three event windows: from one day before to one day after the announcement $C A R(-1,1)$, from one day before to two days after $C A R(-1,2)$, and from one day before to three days after $C A R(-1,3)$. To estimate abnormal returns, we estimate a linear regression of the daily return of each share on the returns of both the Shanghai Composite Index (a measure of A-share market returns) and the Hong Kong Hang Seng Index (a measure of Hong Kong market returns). We use data from 365 days to 10 days before each announcement to estimate the regression coefficients and then use the coefficients to compute the share's daily abnormal returns across

\footnotetext{
${ }^{17}$ We obtain similar results by using A-share EPS deflated by the firm's A-share price, or the average EPS of A and $\mathrm{H}$ shares deflated by their average price..
} 
the announcement. Panel A of Table 3 reports the comparison. It clearly shows that $\mathrm{H}$ shares react more strongly to earnings news than A shares.

In order to control for other factors that might also affect the price reactions of $\mathrm{A}$ and $\mathrm{H}$ shares to earnings news, we follow Bailey, Karolyi, and Salva (2006) to pool $|C A R(-1,1)|$ of both A shares and $\mathrm{H}$ shares for all earnings announcements and run the following regression analysis:

$$
\begin{gathered}
\mid \text { CAR }(-1,1)\left|=\beta_{0}+\beta_{1} H+\beta_{2}\right| \text { Surprise }\left|+\beta_{3} H \cdot\right| \text { Surprise } \mid \\
+\beta_{4} \text { Controls }+\varepsilon .
\end{gathered}
$$

In this regression specification, $H$ is a dummy variable, which equals 1 if the observation is for $H$ shares, and 0 otherwise, and Surprise is the surprise in the reported EPS. Our analysis focuses on the interaction term of $\mid$ Surprise $\mid$ and $H$. If this interaction term has a positive coefficient, it means $\mathrm{H}$ shares react more strongly to surprise in the earnings news. Here we control for size and leverage, which are commonly regarded as important determinants of stock return volatility.

We report the regression results in Panel B of Table 3. We first use simple regression (Model 1), the coefficients of key variables $H$ and the interaction term of $H$ and $\mid$ Surprise $\mid$ are both significantly positive, confirming the observation above that $\mathrm{H}$ shares have stronger reactions to earnings announcement news. The coefficient of the control variable size is significantly negative, indicating that larger firms have weaker market reactions.

We also use an alternative panel regression specification with fixed effect of each earnings announcement (EA effect). As each event has two observations, i.e., reactions of $\mathrm{A}$ and $\mathrm{H}$ shares, this regression is equivalent to a difference model with the dependent variable being the differential price reactions of $\mathrm{A}$ and $\mathrm{H}$ shares. This one-to-one difference helps to control various latent factors associated with every earnings announcement. The second major column of Panel B of Table 3, which is marked by Model 2, reports the regression result. Two of the variables, $\mid$ Surprise $\mid$ and Lev are irrelevant there, as they are replaced by individual fixed-effect dummies. The key interaction term $H \cdot \mid$ Surprise $\mid$ still has a positive and significant coefficient, again confirming stronger reactions of H-share prices to earnings surprises. 
Taken together, by using two different regression specifications, we obtain the same finding that $\mathrm{H}$-share prices react more strongly to earnings news. This pattern is consistent with a significant effect caused by information asymmetry between A-share and H-share investors. ${ }^{18}$

\section{Price Reactions to Analyst Forecast Revisions}

In this section we examine price reactions of $\mathrm{A}$ and $\mathrm{H}$ shares to financial analysts' earnings forecast revisions. Financial analysts regularly release to investors reports on publicly listed firms. These reports are widely recognized in the finance and accounting literature as an important source of information to investors.

A typical report in our sample contains an analyst's forecast of a firm's earnings as well as a categorized recommendation to buy (or sell) the firm's A shares or $\mathrm{H}$ shares. As the A and $\mathrm{H}$ shares have the same cash flow rights, the analyst's earnings forecast contains the same information to both A-share and H-share investors regarding the earnings potential of the firm. However, the analyst's recommendation to buy (or sell) the firm's A shares or $\mathrm{H}$ shares reflects the analyst's judgment of not only the firm's fundamental value but also the general conditions of the specific A-share or H-share markets. To focus on investors' reactions to information specific to the firm, we choose to examine whether A-share and H-share prices might have differential reactions to the revisions of analysts' earnings forecasts, conditional on no changes in their recommendations. ${ }^{19}$

\section{A. Data Sample}

We collect analysts' earnings per share (EPS) forecasts for all firms in our sample from Bloomberg for the period between January 1, 2006 and April 30, 2012. The EPS forecasts are made for the current fiscal year from January 1 to December 31 of each year. We use Bloomberg because it is widely subscribed to by institutions both inside and outside China. An

\footnotetext{
${ }^{18}$ We have also examined post-earnings announcement drift of A-share and $\mathrm{H}$-share prices and found no evidence of any significant difference. It is thus difficult to attribute the differential reactions of A-share and $\mathrm{H}$-share prices to local and foreign investors' attention to earnings announcements.

${ }^{19}$ As recommendation changes are more likely to be accompanied by large forecast revisions, this data filter tends to filter out large forecast revisions and thus make the remaining forecasts in our sample less likely to be influential.
} 
EPS forecast released by Bloomberg is accessible by institutional investors of both $\mathrm{A}$ and $\mathrm{H}$ shares. Thus, we view forecasts released through Bloomberg as public news to all investors.

Following Loh and Stulz (2011), we use several criteria to screen these forecasts. We delete those forecasts made in the three days around quarterly earnings announcements to avoid any earnings-announcement effect. We also delete those forecasts made in the three days around earnings guidance announcements to avoid any earnings-guidance effect. We delete those multiple forecasts made on the same day by multiple houses to avoid the compounding effect of multiple forecasts. As discussed earlier, we remove any forecast that is accompanied by a change in the analyst's recommendation (in a three-day window). We also require a valid EPS forecast to be made by a brokerage or research firm with a known name and to have active trading around the release date in both $\mathrm{A}$ and $\mathrm{H}$ shares of the firm. ${ }^{20}$

Even after applying these filters, we still have a large sample with 14915 EPS forecasts made by analysts from 63 brokerage and research firms (houses). We count a house as Chinese if its controlling shareholders are Chinese corporations and it is incorporated in mainland China, and as foreign if its controlling shareholders are not Chinese corporations and it is incorporated outside the mainland. According to this definition, we have 33 Chinese houses and 25 foreign houses. The former list includes almost all of the major brokerage firms inside mainland China such as China International Capital Corporation, Citic Securities, China Merchants Securities, and SWS Research Co Ltd., while the latter includes brokerage and research firms from all over the world, such as Credit Suisse, BNP Paribas, Nomura, and Sanford Bernstein. To focus on the comparison of price reactions to forecasts made by analysts of Chinese and foreign houses, we exclude analysts from the remaining 5 houses, which are neither Chinese nor foreign. This leaves us 11077 forecasts. In these forecasts, 8740 are upward revisions, which is $78.9 \%$ of the sample. This fraction is consistent with a common observation that analysts tend to revise earnings forecasts upward.

In the final sample, there are 5805 forecasts by analysts of Chinese houses and 5272 forecasts by analysts of foreign houses. This sample is roughly balanced between Chinese houses

\footnotetext{
${ }^{20}$ We match a given forecast for $\mathrm{A}$ or $\mathrm{H}$ shares by a house with the house's previous forecast and the consensus forecast for the same share type of the firm. That is, an EPS forecast for A shares is matched with the consensus forecast for the firm's A shares.
} 
and foreign houses. In the revisions made by Chinese houses, 4373 are upward revisions, with a fraction of $75.3 \%$ that is close to $78.9 \%$ of the full sample. In the revisions made by foreign houses, 4367 forecasts are upward revisions.

Based on the address and phone numbers provided by Bloomberg for most analysts, we are able to locate the analysts of 7758 forecasts in our sample. Among the 4751 forecasts made by Chinese houses, 4436, or 93.4\%, are by analysts physically located in mainland China. Among the 3007 forecasts made by foreign houses, 2314, or $76.9 \%$, are by analysts working outside mainland China.

Figure 2 depicts the sample distribution of forecast revisions across firms and over time. In Panel A, each bar indicates the total number of forecast revisions regarding a firm. This number is split into two parts, with the top part of the bar indicating the number of forecast revisions made by foreign analysts while the bottom part indicating the number of revisions by local analysts. There are 65 firms with valid forecast revisions. The number of forecasts revisions for a firm ranges from 2 to $325 .^{21}$ More importantly, the forecast revisions for each firm are well balanced between Chinese houses and foreign houses, invalidating a concern that Chinese houses follow one set of firms while foreign houses follow another set.

Panel B depicts the sample distribution of forecast revisions over time. Most of the forecast revisions are made after 2009. This is consistent with the increasing number of dual listed firms and the growing analyst activities about Chinese stocks. Again, we note that the balance of forecast revisions made by Chinese houses and foreign houses is stable over time.

\section{B. Influential Forecast Revisions}

As highlighted by Loh and Stulz (2011), due to the large number of earnings forecasts and recommendations regularly made by analysts, many of the forecasts and recommendations are noisy even though some of them do contain useful information and can significantly move stock prices. To deal with the large amount of noise in an average analyst forecast or recommendation,

\footnotetext{
${ }^{21}$ The sample period for some firms is particularly short and explains the small number of valid forecast revisions for them. According to Figure 1, 10 of the 71 firms in our sample issued both A and H shares only after January 2011. This short period explains why six of the firms in our sample have no forecast revisions.
} 
Loh and Stulz (2011) propose to analyze the impact of a subset of influential forecasts and recommendations---i.e., those that visibly move stock prices---rather than the average forecast and recommendation. Specifically, they define a forecast revision or recommendation change to be influential if it leads to a statistically significant abnormal stock return in the same direction as the forecast revision or recommendation change.

Motivated by their analysis, we test the Trust-Based Hypothesis by examining whether a forecast revision given by a local or foreign house is more likely to be influential among A-share or H-share investors. We classify a forecast revision as bad news if the new forecast is lower than the house's previous forecast. Otherwise, we classify the forecast as good news. We define a forecast revision to be influential among A-share (or H-share) investors if the share's cumulative abnormal return from one day before to one day after the release of the forecast, $C A R(-1,1)$, is in the same direction as the news and the absolute value of $C A R(-1,1)$ exceeds $\sigma_{r} \times \sqrt{3} \times 1.96$, where $\sigma_{r}$ is the share's idiosyncratic volatility, 3 is the length of the three-day return period, and 1.96 corresponds to the $2.5 \%$ significance level of normal distribution. By this definition, we expect $2.5 \%$ of the forecast revisions to be influential by pure chance. Like before, to calculate $\operatorname{CAR}(-1,1)$ and the share's idiosyncratic volatility $\left(\sigma_{r}\right)$, we estimate a linear regression of the daily return of each share on the returns of both the Shanghai Composite Index and the Hong Kong Hang Seng Index. We use data from 365 days to 10 days before each forecast.

Table 4 summarizes the number of influential forecasts. In the sample of 5272 forecasts made by foreign houses, 165 of them are influential among A-share investors while 270 are influential among the $\mathrm{H}$-share investors. In terms of percentage, 3.13\% of these forecast revisions are influential among A-share investors while 5.12\% are influential among H-share investors. Loh and Stulz (2011) analyze a sample of analyst forecasts about earnings of U.S. firms in Thomson Financial's I/B/E/S database and find the fraction of influential forecast revisions to be around 5\%. The percentage of influential forecasts among the H-share investors is at the same level as that in the U.S. data and higher than $2.5 \%$ (the level implied by pure noise) with a highly significant t-statistic of 8.63. More important, the fraction among H-share investors is $1.99 \%$ higher than the fraction among A-share investors and this difference is 
significant with a t-statistic of 5.54. This difference indicates that forecast revisions by foreign analysts are more likely to be influential among H-share investors than among A-share investors.

Similarly, in the sample of 5805 forecasts made by local houses, 208 of them are influential among A-share investors while 155 are influential among H-share investors. In percentage terms, the fraction of influential forecast revisions among A-share investors is 3.58\%, which is higher than $2.5 \%$ with a significant t-statistic of 4.44 . This fraction is $0.91 \%$ higher than that among Hshare investors and the difference is also significant with a t-statistic of 3.06. This difference indicates that forecast revisions made by local houses are more likely to be influential among Ashare investors than among H-share investors.

In our sample, 730 forecast revisions are influential in either A or $\mathrm{H}$ market. Among them, 68 forecast revisions (9.3\%) are influential in both $\mathrm{A}$ and $\mathrm{H}$ market. ${ }^{22}$ These 68 forecast revisions are almost evenly made by Chinese house and foreign houses (31 and 37 respectively). 651 (or 89\%) of the 730 influential forecast revisions are upward revisions.

Figure 3 presents the distribution of these 730 influential forecast revisions across firms. Each bar in the figure indicates the number of influential forecast revisions made for a firm. The top part of the bar indicates the number of influential forecast revisions made by foreign analysts while the bottom part is the number made by local analysts. In the sample, 60 firms have influential forecasts. The number of influential forecasts for a firm ranges from 1 to 29 , and is well balanced across analysts of local and foreign houses.

We also vary the $2.5 \%$ significance level in the definition of influential forecast revisions to $0.5 \%$. That is, a revision is influential if the associated cumulative abnormal return CAR(-1,1) of the share is in the same direction of the news with an absolute value exceeding $\sigma_{r} \times \sqrt{3} \times 2.57$, where 2.57 corresponds to the $0.5 \%$ significance level of normal distribution. Based on the $0.5 \%$ significance level, Panel B of Table 5 summarizes the number of influential forecast revisions made by both foreign and local houses among A-share and H-share investors. We observe a similar symmetric pattern that revisions made by foreign houses are more likely to be influential

\footnotetext{
${ }^{22}$ The fact that less than $10 \%$ of the influential forecast revisions are influential in both $\mathrm{A}$ and $\mathrm{H}$ markets demonstrates that the significant market reactions associated with the influential forecast revisions are unlikely caused by important corporate events.
} 
among H-share investors than among A-share investors, while revisions made by local houses are more likely to be influential among A-share investors. ${ }^{23}$

\section{Logit Regressions}

To verify that the differential reactions of $\mathrm{A}$ and $\mathrm{H}$ shares are robust to controls for other factors, we follow Loh and Stulz (2011) to use a logit regression approach. Specifically, we pool forecast revisions by analysts of either local or foreign houses to run the following logit regression:

$$
\text { inf }=\beta_{0}+\beta_{1} H+\beta_{2} \text { Controls }+\varepsilon
$$

where the dependent variable inf is a dummy variable, which takes the value of 1 if the revision is influential and 0 otherwise, and the key explanatory variable $H$ is also a dummy variable, which takes the value of 1 if the observation is for $\mathrm{H}$ shares and 0 if it is for $\mathrm{A}$ shares. In this logit regression, we treat reactions of $\mathrm{A}$ and $\mathrm{H}$ shares to a given forecast revision as two observations, and pool them to construct the sample.

We separate forecast revisions made by local houses from those made by foreign houses. When running the logit regression in (2) in the sample of revisions made by local houses, we examine whether $\beta_{1}$, the coefficient of the dummy variable $H$, is negative, i.e., whether revisions made by local analysts are less likely to be influential among H-share investors. On the other hand, in the sample of revisions made by foreign houses, we examine whether $\beta_{1}$ is positive, i.e., whether revisions by foreign houses are more likely to be influential among H-share investors. In this analysis, we implicitly treat analysts working for local houses as local analysts and those working for foreign houses as foreign analysts. In the next subsection, we further separate local and foreign analysts of the same foreign houses, based on their family names.

We include three types of control variables in the regression: analyst characteristics, firm characteristics, and market characteristics. We use several analyst characteristics to capture

\footnotetext{
${ }^{23}$ We have also used longer event windows to measure influential forecast revisions, such as $C A R(-2,1)$ and $C A R(-$ $2,2)$. These alternative measures lead to similarly symmetric patterns in the number of influential forecast revisions of local and foreign houses in the A- and H-share markets, even though the longer windows introduce greater noise and make the differences less significant.
} 
analysts' forecast ability. These variables include the following. We measure an analyst's experience (experience) by the number of quarters the analyst has been covering a firm minus the average experience for all analysts covering the firm. To measure the accuracy of an analyst's previous forecast (accuracy), we compute for each forecast in our sample the analyst's forecast errors by the absolute forecast error divided by the firm's average A-share and H-share price at the end of the previous year, and then sort errors of all forecast observations into 5 quintiles and an analyst's quintile in the previous year as the measure of accuracy. We also use a dummy variable to measure whether the analyst has previously made any influential forecast revision on the same firm (Inf_lag). It takes the value of 1 if the analyst has previously made an influential revision on the same firm and 0 otherwise. We include this variable due to the argument that analysts' skills are likely to be persistent and, as a result, having previously made an influential forecast revision makes his future revisions more likely to be influential as well. We also include another dummy variable to measure whether a forecast is further away from the consensus forecast (boldness). Specifically, it takes the value of 1 if the current forecast deviates further from the consensus than the analyst's prior forecast and 0 otherwise. This variable captures the forecast's boldness.

We also include several firm characteristics to capture uncertainty faced by investors in trading a firm's shares: the ratio of a firm's book value to market value $(B M)$, firm size, analyst coverage (coverage), and analysts' forecast dispersion (dispersion). Intuitively, a forecast revision is more likely to be influential if investors face greater uncertainty about the firm's earnings. It is often argued that growth firms are more uncertain as their fundamental values rely more on growth options rather than steady cash flows. We use the book-to-market ratio to control for growth firms as they tend to have lower book-to-market ratios than value firms. We also include firm size and analyst coverage as investors face a less transparent information environment for small firms and firms with less analyst coverage. We measure firm size by a logarithm of the market value of all tradable shares in one class at the end of the previous year. We separately measure the size of $\mathrm{A}$ shares and $\mathrm{H}$ shares of each firm. We measure analyst coverage by the number of analysts that cover a given firm in a given year. Furthermore, we include dispersion of analysts' EPS forecasts---calculated by the ratio of standard deviation to the mean of all forecasts made by all analysts for a given firm in the year before each news event 
---as another measure of the firm's information uncertainty. It is intuitive that great analysts' forecast dispersion implies greater information uncertainty faced by investors.

We also include the fraction of tradable shares held by retail investors (retail) as a control variable. As retail investors may not subscribe to Bloomberg and other news portals, they do not have equal access to analyst reports as institutional investors. We separately measure this variable for both $\mathrm{A}$ and $\mathrm{H}$ shares of each firm. The summary information given in Table 1 shows that the fraction of tradable $\mathrm{A}$ and $\mathrm{H}$ shares held by retail investors is roughly the same. Thus, we do not expect A-share and H-share investors in aggregate to have differential access to analyst reports. Nevertheless, we include retail as a control variable in our analysis to capture heterogeneity of retail investor ownership across firms and across announcement events.

Finally, we also include several market variables to control for market factors that might affect stock returns during the event period. These variables include turnover rate (turnover), return volatility (volatility), and return momentum (momentum). These variables can also help control for a concern about endogenous timing of analyst forecasts. Specifically, local analysts may choose to release their forecasts during periods of high volatility (high sentiment) in A-share markets, while foreign analysts may release their forecasts in periods of high volatility (high sentiment) in H-share markets. To control for this concern, we measure both return volatility and return momentum in a short period (one week) prior to forecast announcements. Following the standard procedure in the literature, we take a logarithmic transformation of both turnover rate and volatility in the regression.

Table 5 reports the summary statistics of all control variables. All of these control variables are winsorized to $1 \%$ or $99 \% .{ }^{24} \mathrm{~A}$ few comments are worthwhile here. The mean and median of experience is 0.540 and 0.679 , respectively. They are almost zero because experience is a relative measure---the duration of each analyst's coverage of a firm subtracted by the average duration of all analysts for each firm-year observation. The mean of boldness is 0.331, which indicates that about $30 \%$ of forecasts are moving away from the consensus relative to the

\footnotetext{
${ }^{24}$ Winsorizing the control variables does not affect our results. Due to the availability of data, the number of observations for each control variable also varies.
} 
analysts' prior forecasts. Consistent with the pattern in Table 1, the return volatility of $\mathrm{H}$ shares is larger than that of A shares, and the turnover rate of $\mathrm{H}$ shares is less than that of $\mathrm{A}$ shares.

Table 6 separately reports the logit regression results for the samples of forecast revisions made by local and foreign houses. We compute t-statistics in the regressions using standard deviation clustered in firm/analyst pairs. In the sample of forecast revisions made by local houses (left panel), the first major column (marked as Model 1) reports the result from a baseline regression without including any control variable. The coefficient of the key dummy variable $H$ is significantly negative with a t-statistic of -2.99 . The second major column (marked as Model 2) reports the result from a full regression with all the control variables. Due to the availability of some of the control variables, the number of observations is reduced to 3501 . The coefficient of $H$ is again significantly negative with a t-statistic of -1.99 . Taken together, these regressions confirm that forecast revisions made by local houses are significantly less likely to be influential among H-share investors than among A-share investors.

In the sample of forecast revisions made by foreign houses, we repeat the same baseline and full regressions with the results reported in major columns 3 and 4 of Table 6 (right panel). The coefficient of $H$ is significantly positive with a t-statistic of 4.34 in the baseline regression, and is positive with a significant t-statistic of 1.74 in the full regression. Taken together, these regressions demonstrate that forecast revisions made by foreign houses are significantly more likely to be influential among H-share investors than among A-share investors.

Among the control variables, the coefficient of analyst coverage is negative in both samples and, in particular, is significant in the sample of forecast revisions made by foreign houses. This negative coefficient is consistent with the notion that greater analyst coverage improves a stock's information environment and thus reduces the impact of analysts' individual forecasts. The coefficient of volatility is positive and significant in both samples, which is consistent with the notion that greater fundamental uncertainty makes analysts' earnings forecasts more likely to be influential. The coefficients of retail investor ratio, size, and price momentum are all positive and significant in both samples. The coefficients of other control variables are insignificant.

Taken together, our analysis shows that forecast revisions made by local houses are significantly more likely to be influential among A-share investors while forecast revisions made 
by foreign houses are significantly more likely to be influential among H-share investors. This symmetric pattern in the differential reactions of A-share and H-share investors is in sharp contrast to that of their reactions to earnings news with H-share investors always reacting more strongly. To the extent that the effect of information asymmetry may also affect the reactions of investors' reactions to analysts' forecast revisions and offset the trust effect by causing $\mathrm{H}$-share investors to react more strongly to the forecast revisions by local houses, our finding of A-share investors nevertheless reacting more strongly is a significant piece of evidence supporting the presence of the trust effect dominating the information asymmetry effect.

Neither can one attribute the symmetric pattern in the differential reactions of A-share and $\mathrm{H}$-share investors to the forecasts of either local or foreign houses being more accurate. We will separately explore this issue in a later subsection. As long as both A-share and $\mathrm{H}$-share investors agree on the forecast precision of local and foreign houses, we expect them to react to a given forecast revision in the same way if they are equally informed about the firm, or H-share investors to always react more strongly if $\mathrm{H}$-share investors are less informed as suggested by the information asymmetry theory. Thus, without acknowledging A-share and H-share investors' disagreement about the precision of the forecasts, it is difficult to explain why H-share investors systematically react more strongly to the forecasts of foreign house and less strongly to the forecasts of local houses. Instead, our finding suggests that despite the better accuracy of the forecasts of local houses, $\mathrm{H}$-share investors attribute a higher precision to the forecasts of foreign houses and a lower precision to the forecasts of local houses, which is consistent with the TrustBased Hypothesis.

\section{Difference-in-Difference Analysis}

In our earlier analysis, we treat analysts working for local houses as local analysts and for foreign houses as foreign analysts. In this subsection, we further explore the heterogeneity within analysts of foreign houses and within analysts of local houses. It is common for foreign

houses to hire Chinese analysts to cover Chinese firms, although it is rare for local houses to hire non-Chinese analysts. If the stronger reactions of $\mathrm{H}$ shares relative to A shares to the forecast revisions of foreign houses are driven by social trust, we expect this trust effect to be stronger among the subsample of forecast revisions made by non-Chinese analysts relative to the 
subsample of forecast revisions by Chinese analysts. This consideration motivates a differencein-difference analysis of the price reactions of $\mathrm{A}$ and $\mathrm{H}$ shares to forecast revisions of foreign houses.

While local brokerage and research firms typically hire only Chinese analysts, some of them are educated inside mainland China while others are educated outside. To the extent that Chinese analysts educated outside mainland China are more exposed to non-Chinese culture and are more familiar with investment philosophies and strategies of foreign investors, it is reasonable to argue that their social distance to H-share investors is closer than that of Chinese analysts educated inside mainland China. Thus, the variation in educational background of Chinese analysts of local houses allows another difference-in-difference analysis to examine whether the stronger price reactions of A shares relative to $\mathrm{H}$ shares to the forecast revisions of local houses are more pronounced in the subsample of analysts educated inside mainland China than in the subsample of analysts educated outside.

These difference-in-difference analyses also allow us to control for several arguments about local and foreign investors having differential access to reports of local and foreign houses. First, it may be easier for A-share investors to access reports and contact analysts of local houses and $\mathrm{H}$-share investors to obtain reports and contact analysts of foreign houses. As investors (A-share or H-share investors) have the same access to reports by local and foreign analysts of the same foreign houses, comparing price reactions of $\mathrm{A}$ and $\mathrm{H}$ shares to these reports naturally controls for this accessibility issue. Second, the working language of local houses is Chinese while that of foreign houses is English. Bloomberg releases the abstract of all analyst reports in both Chinese and English, and the main body of some of the reports in both languages. Whether the main body of a report is available in both languages depends on whether the issuing house provides both versions. As a foreign house is equally likely to translate reports of its local and foreign analysts and a local house is equally likely to translate reports of its locally educated and foreign educated analysts, comparing price reactions of $\mathrm{A}$ and $\mathrm{H}$ shares to different subsamples of reports from the same local or foreign houses again controls for this language issue. Finally, the differential access to analysts of local and foreign houses may also make local investors more informed about the competence of individual analysts of local houses and foreign investors more informed about the competence of individual analysts of foreign houses. 
Bloomberg provides the name of the analyst for each analyst report. Analyst name allows us to identify whether an analyst is Chinese. Specifically, we define an analyst as Chinese if his last name is based on Pinyin, the official phonetic system for transcribing the sound of Chinese characters into Latin script, and as foreign otherwise. We use family name as the criterion because it is rare for Chinese to adopt foreign family names even though it is common for them to use Western first names.

Note that A-share investors are primarily residents of mainland China, while $\mathrm{H}$-share investors are mixed with residents from outside mainland China, including Chinese speaking regions such as Hong Kong, Taiwan, Singapore, and other parts of the world such as the U.S., the U.K., and continental Europe. In light of our discussion in Section II, if the differential reactions of A-share and $\mathrm{H}$-share investors are driven by their differential trust and social connections to the analysts, it is useful to separate analysts with origins inside mainland China from those with origins in Hong Kong, Taiwan, and Singapore even though they can also speak Chinese. To do so, we take advantage of the fact that the Pinyin systems used in mainland China, Hong Kong, Taiwan, and Singapore are different from each other. Specifically, by potentially abusing the term "Chinese," we define an analyst as Chinese only if his family name matches Pinyin used in mainland China. ${ }^{25}$ It is easy for both local and foreign investors to recognize an analyst whose family name matches this criterion as coming from a family in mainland China. ${ }^{26}$

In Table 7, we focus on the analyst forecasts made by foreign houses that have both Chinese and non-Chinese analysts in our sample. Because some foreign houses have only non-Chinese analysts and some forecasts do not have analyst names, this restriction leads to a reduction in the sample size of analyst forecasts (relative to the last column of Table 6). Specifically, we have 1205 forecasts made by non-Chinese analysts of foreign houses and 1435 forecasts made by Chinese analysts.

\footnotetext{
${ }^{25}$ We also check the given name in the case that the Pinyin of the family name in the mainland system coincides with that used outside the mainland.

${ }^{26}$ This criterion is different from Bae, Stulz, and Tan (2008), who define an analyst as local if her address is close to the firm she covers. We believe that our family-name based definition is better suited for our analysis of trust and social connections between investors and analysts, while their distance based definition fits better for their focus on analyzing the informational advantage of local analysts.
} 
In the first and second major columns of Table 7, we repeat regression (2) in the subsamples of forecasts made by non-Chinese and Chinese analysts. The estimate of the key coefficient $H$ is positive and significant in the subsample of forecasts by non-Chinese analysts, but positive and insignificant in the subsample of forecasts by Chinese analysts. The magnitude of this coefficient in the former subsample is 0.671 , which is clearly larger than 0.049 in the latter subsample.

To explicitly compare the differential reactions of A-share and H-share investors to these two subsamples of analyst forecasts, we run the following regression:

$$
\begin{aligned}
\text { inf }= & \beta_{0}+\beta_{1} H+\beta_{2} \text { NonChineseAnalyst }+\beta_{3} H * \text { NonChineseAnalyst } \\
& +\beta_{4} \text { Controls }+\beta_{5} \text { NonChineseAnalyst } * \text { Controls }+\varepsilon .
\end{aligned}
$$

Like regression (2), the dependent variable inf is a dummy variable, which takes the value of 1 if the forecast revision is influential and 0 otherwise. The dummy variable $H$ takes the value of 1 if the observation is for $\mathrm{H}$ shares and 0 otherwise. The dummy variable NonChineseAnalyst takes the value 1 if the forecast is made by a non-Chinese analyst and 0 otherwise. The coefficient $\beta_{3}$ of the interaction term $H *$ NonChineseAnalyst measures a difference-indifference effect---whether the differential reaction of A-share and $\mathrm{H}$-share investors is more pronounced in forecasts made by non-Chinese analysts than those by Chinese analysts. Besides the same set of control variables as in regression (2), we also include their interaction terms with the NonChineseAnalyst dummy as control variables.

To save space, we report only the coefficients for all interaction terms with the NonChineseAnalyst dummy in the third major column of Table 7. The coefficient of the interaction term $H *$ ChineseAnalyst (coefficient $\beta_{3}$ in regression (3)) takes a positive value of 0.623 and is significant. This confirms that within forecasts of foreign houses, the stronger reactions of $\mathrm{H}$-share investors are more pronounced to forecasts made by non-Chinese analysts than to those by Chinese analysts. As this regression directly compares forecasts made by Chinese and non-Chinese analysts of the same houses, one cannot simply attribute the differential price reactions of $\mathrm{A}$ and $\mathrm{H}$ shares to either the differential accessibility of A-share and $\mathrm{H}$-share investors to the analyst reports or different languages of the analyst reports. Instead, 
this result directly relates the differential price reactions to attributes of Chinese and non-Chinese analysts. This result thus further supports the Trust-Based Hypothesis.

In Table 8, we focus on the sample of forecasts made by local houses that have both foreigneducated and locally educated analysts. Bloomberg provides phone numbers and email addresses for most of the analysts. We have manually contacted these analysts and asked their educational background. Due to some missing contact information in Bloomberg, some analysts having changed jobs, and some analysts refusing to respond to our background inquiry, there has been a reduction in the sample size. We have used LinkedIn to mitigate this sample reduction. Finally, we have 501 forecasts made by foreign-educated Chinese analysts of local houses and 1053 forecasts made by locally educated Chinese analysts.

In the first and second major columns of Table 8, we repeat regression (2) in the subsamples of forecasts made by locally educated and foreign-educated Chinese analysts in local houses. The estimate of the key coefficient $H$ is significantly negative in the subsample of forecasts by locally educated Chinese analysts with a magnitude of -0.682. This differential reaction between Ashare and H-share prices is larger than the full sample of forecasts made by analysts of local houses, which is shown in the second major column of Table 6 with a magnitude of -0.303 . In the subsample of forecasts by foreign-educated Chinese analysts, the estimate of $H$ is positive and insignificant with a magnitude of 0.423 . This positive differential reaction means that $\mathrm{H}$ share prices have a stronger reaction than A-share prices to the forecasts of foreign-educated Chinese analysts, albeit insignificant.

We also run the following regression to explicitly compare the differential reactions of Ashare and H-share prices to these two subsamples of analyst forecasts:

$$
\begin{aligned}
\text { inf }=\beta_{0}+\beta_{1} H+ & \beta_{2} \text { LocalEduAnalyst }+\beta_{3} H * \text { LocalEduAnalyst } \\
& +\beta_{4} \text { Controls }+\beta_{5} \text { LocalEduAnalyst } * \text { Controls }+\varepsilon .
\end{aligned}
$$

This regression is otherwise the same as regression (3), except replacing the dummy variable NonChineseAnalyst by another dummy variable LocalEduAnalyst, which takes the value of 1 if the analysts is locally educated and 0 otherwise. To save space, we report only the coefficients of all interaction terms with this analyst dummy in the third major column of Table 8. 
The key coefficient $\beta_{3}$, which measures the difference-in-difference effect, takes a negative value of -1.106 and is significant. This result confirms that within forecasts of local houses, the weaker reactions of $\mathrm{H}$-share investors are more pronounced to forecasts made by locally educated Chinese analysts than to those by foreign-educated analysts. This result again supports the Trust-Based Hypothesis.

\section{E. Accuracy of Local and Foreign Analysts}

It is useful to examine whether there is any systematic difference between local and foreign analysts in their ability to predict firm earnings. We adopt the following regression:

$$
\operatorname{err}_{i t j}=\beta_{0}+\beta_{1} \text { Local }_{i t j}+\beta_{2} D_{i t j}+\beta_{i t}+\varepsilon
$$

where the dependent variable err $_{i t j}$ is the ex post forecast error (difference between the realized and forecasted earnings) deflated by the previous year-end share price (the average of A-share and $\mathrm{H}$-share prices) for the $j$-th forecast revision made for firm $i$ in fiscal year $t$. The key explanatory variable Local $_{i t j}$ is a dummy variable, which takes the value of 1 if the forecast is made by a local house and 0 other wise. We include $D_{i t j}$, the number of days between the forecast announcement and the actual earnings announcement, as a control variable because firm earnings are easier to forecast when the announcement date becomes closer.

Many firm characteristics may affect analysts' forecast accuracy, for example, the earnings predictability. To better control for these firm characteristics, we use a panel data fixed effect model, i.e., there is a dummy variable for each firm/year pair in the regression $\left(\beta_{i t}\right)$. This dummy variable captures the effect of all firm characteristics in this panel regression.

The regression results using the full sample are reported in Panel A of Table 9. In the first major column (Model 1), we provide a simple comparison without including the firm/year fixed effect variable. The parameter estimator for the local variable is almost zero, indicating no significant difference between local and foreign analysts in their ability to predict firm earnings. The coefficient of $D$ is significantly positive, which is consistent with the fact that firm earnings are easier to forecast when it is closer to the announcement date. When the firm/year fixed effect is controlled in the second major column (Model 2), the coefficient of local is still insignificant, 
showing that forecasts made by Chinese houses are not significantly different from that of foreign houses.

Hong and Kubik (2003) suggest a ranking method to examine analysts' earnings forecast accuracy. Following their approach, we rank the forecast errors defined above within each firm/year into 10 groups, and then use this rank, accrank, as the dependent variable to re-run the regression in (5). The regression results are reported in Model 3 and Model 4 of Panel A in Table 9. In this case, the results are similar to the absolute error that there is no significant difference between local houses and foreign houses.

We further examine the forecasting accuracy of local and foreign analysts in the two subsamples. Panel B is for the subsample of forecast revisions made by foreign houses. To examine whether there is any systematic difference between Chinese and non-Chinese analysts within this subsample, we replace the Local dummy in (5) by a dummy ChineseAnalyst, which is determined by the last name of the analyst, as described in the previous subsection. The coefficient of ChineseAnalyst is negative in all models and significant in Model 2, 3, and 4, showing that forecasts made by Chinese analysts of foreign houses are significantly more accurate than those by non-Chinese analysts of foreign houses. This finding is consistent with Du, Yu, and Yu (2014), who show that among a set of U.S. analysts who cover Chinese firms listed in the U.S. stock markets, analysts with Chinese ethnic origin, especially those first-generation Chinese immigrants, issue more accurate forecasts than non-Chinese analysts.

Panel $\mathrm{C}$ is for the subsample of forecast revisions made by local houses. To examine the difference between analysts of local houses with or without education outside China, we replace the Local dummy in (5) by a dummy ChinaEdu, which indicates whether an analyst is educated only inside China. The coefficient of this dummy is insignificant in 3 of the 4 models, showing that the forecasts made by analysts of local houses with education only inside China is not significantly more accurate than those educated overseas.

Taken together, the results reported in Table 9 show that there is not any significant difference between the accuracy of forecasts made by local and foreign houses, and that Chinese analysts of foreign houses tend to issue more accurate forecasts than non-Chinese analysts of foreign houses. As we discussed earlier, whether the forecasts of local or foreign analysts are 
more accurate does not explain our key findings of A-share investors reacting more strongly to the forecasts of local analysts and H-share investors reacting more strongly to the forecasts of foreign analysts.

\section{Conclusion}

This paper uses the segmented dual-class shares of Chinese firms to analyze the differential reactions of local and foreign investors to the same public news. We find that local investors react more strongly to earnings forecast revisions of local analysts, while foreign investors react more strongly to forecast revisions of foreign analysts. This finding cannot be explained by local investors being more informed about local firms, earnings forecasts of local analysts being more precise, or local investors having better access to reports of local houses. Instead, it supports the notion that local investors have more trust for local analysts and foreign investors have more trust for foreign analysts. Our analysis thus highlights social trust as an important force driving people react differently to the same information.

Our finding sheds light on an important source of heterogeneity in financial markets. As investors have different trust for different analysts, gurus or other sources of information, they are likely to hold different beliefs about the same financial asset and, as a result, to speculate against each other. This helps explain the widely observed excessive trading in asset markets. This insight is particularly useful in understanding international investments. Foreign investors face more severe informational barriers in investing in local assets. To mitigate the informational barriers, it is beneficial for them to hire better informed local analysts or local money managers to facilitate their investment decisions. However, as emphasized by Gennaioli, Shleifer, and Vishny (2013), trust is the key in maintaining the relationship between investors and money managers. The lack of trust may prevent foreign investors from effectively relying on the expertise of local analysts and local money managers to overcome their informational barriers. This helps explain the widely documented home bias in portfolio investments of investors across the world and why equity holdings of foreign investors tend to be highly volatile. 


\section{References}

Amihud, Yakov (2002), Illiquidity and stock returns: Cross-section and time-series effects, Journal of Financial Markets 5, 31-56.

Bae, Kee-Hong, René M. Stulz, and Hongping Tan (2008), Do local analysts know more? A cross-country study of the performance of local analysts and foreign analysts, Journal of Financial Economics 88, 581-606.

Bailey, Warren and Julapa Jagtiani (1994), Foreign ownership restrictions and stock prices in the Thai capital market, Journal of Financial Economics 36, 57-87.

Bailey, Warren, Andrew Karolyi, and Carolina Salva (2006), The economic consequences of increased disclosure: Evidence from international cross-listings, Journal of Financial Economics 81, 175-213.

Baker, Kent, John Nofsinger, and Daniel Weaver (2002), International cross-listing and visibility. Journal of Financial and Quantitative Analysis 37, 495-521.

Bohn, Henning and Linda Tesar (1996), US equity investment in foreign markets: portfolio rebalancing or return chasing?, American Economic Review 86, 77-81.

Brennan Michael and Huining Cao (1997), International portfolio investment flows, Journal of Finance 52, 1851-1880.

Cao, Huining and Hui Ou-yang (2009), Differences of opinion of public information and speculative trading in stocks and options, Review of Financial Studies 22, 299-335.

Chan, Kalok, V. Covrig, and Lilian Ng (2005), What determines the domestic bias and foreign bias? Evidence from mutual fund equity allocations worldwide, Journal of Finance 60, 14951534.

Chan, Kalok, Albert Menkveld, and Zhishu Yang (2008), Information asymmetry and asset prices: Evidence from the China foreign share discount, Journal of Finance 63, 159-196.

Chen, Zhiwu and Peng Xiong (2002), Discounts on illiquid stocks: evidence from China, Working paper, Yale University.

Choe, Hyuk, Bong-Chan Kho, and Rene M. Stulz (1999), Do foreign investors destabilize stock markets? The Korean experience in 1997, Journal of Financial Economics 54, 227-264.

Coeurdacier, Nicolas and Helene Rey (2011), Home bias in open economy financial macroeconomics, Journal of Economic Literature, forthcoming.

Dornbusch, Rudiger and Yung Chul Park (1995), Financial integration in a second-best world: Are we still sure about our classical prejudices, In: Dornbusch, R., Park, Y.C. (Eds.), Financial Opening: Policy Lessons for Korea, Korea Institute of Finance, Seoul, Korea.

Du, Qianqian, Frank Yu, and Xiaoyun Yu (2014), Cultural proximity and the processing of financial information, Working Paper. 
Dumas, Bernard, Alexander Kurshev, and Raman Uppal (2009), Equilibrium portfolio strategies in the presence of sentiment risk and excess volatility, Journal of Finance 64, 579-629.

Dumas, Bernard, Karen Lewis, and Emilio Osambela (2011), Differences of opinion and international equity markets, NBER Working Paper 16726.

Fama, Eugene and Kenneth French (1992), The cross-section of expected stock returns, Journal of Finance 47, 427-465.

Fernald, John and John Rogers (2002), Puzzles in the Chinese stock market, Review of Economics and Statistics 84, 416-432.

French, Kenneth and James Poterba (1991), Investor diversification and international equity markets, American Economic Review 81, 222-226.

Froot, Kenneth and Emil Dabora (1999), How are stock prices affected by the location of trade? Journal of Financial Economics 53, 189-216.

Froot, Kenneth, Paul O’Connell, and Mark Seasholes (2001), The portfolio flows of international investors, Journal of Financial Economics 59, 151-193.

Gehrig, Thomas (1993), An information based explanation of the domestic bias in international equity investment, Scandinavian Journal of Economics 95, 97-109.

Gennaioli, Nicola, Andrei Shleifer, and Robert Vishny (2013), Money doctors, Journal of Finance, forthcoming.

Gentzkow, Matthew and Jesse Shapiro (2006), Media bias and reputation, Journal of Political Economy 114, 280-316.

Grinblatt, Mark and Matti Keloharju (2001), How distance, language, and culture influence stockholdings and trades, Journal of Finance 56, 1053-1073.

Guiso, Luigi, Paola Sapienza, and Luigi Zingales (2008), Trusting the stock market, Journal of Finance 63, 2557-2600.

Guiso, Luigi, Paola Sapienza, and Luigi Zingales (2009), Cultural biases in economic exchange?, Quarterly Journal of Economics 124, 1095-1131.

Harris, Milton and Artur Raviv (1993), Differences of opinion make a horse race, Review of Financial Studies 6, 473-506

Hirshleifer, David and Siew Hong Teoh (2003), Limited attention, financial reporting, and disclosure, Journal of Accounting and Economics 36, 337-386.

Hong, Harrison and Jeremy C. Stein (2007), Disagreement and the stock market, Journal of Economic Perspectives 21, 109-128.

Hong, Harrison and Jeffrey D. Kubik (2003), Analyzing the analysts: Career concerns and biased earnings forecasts, Journal of Finance 58, 313-351. 
Jegadeesh, N. and Sheridan Titman (2001), Profitability of momentum strategies: An evaluation of alternative explanations, Journal of Finance 56, 699-720.

Karolyi, Andrew and Lianfa Li (2003), A resolution of the Chinese discount puzzle, Working paper, Cornell University.

Kandel, Eugene and Neil Pearson (1995), Differential interpretation of public signals and trade in speculative markets, Journal of Political Economy 103, 831-872.

Lang, Mark, Karl Lins, and Darius Miller (2003), ADRs, analysts, and accuracy: does cross listing in the US improve a firm's information environment and increase market value? Journal of Accounting Research 41, 317-346.

Lee, Charles, Kevin Li, and Ran Zhang (2014), Shell game: The long term performance of Chinese reverse merger firms, Accounting Review, forthcoming.

Lewis, Karen (2011), Global asset pricing, Annual Review of Financial Economics 3, 435-466.

Loh, Roger and René M. Stulz (2011), When are analyst recommendation changes influential?, Review of Financial Studies 24, 593-627.

Mei, Jianping, Jose Scheinkman and Wei Xiong (2009), Speculative trading and stock prices: evidence from Chinese A-B share premia, Annuals of Economics and Finance 10, 225-255.

Mullainathan, Sendhil and Andrei Shleifer (2005), The market for news, American Economic Review 95: 1031-1053.

Peng, Lin and Wei Xiong (2006), Investor attention, overconfidence and category learning, Journal of Financial Economics 80, 563-602.

Portes, Richard and Helene Rey (2005), The determinants of cross border equity flows, Journal of International Economics 65, 269-296.

Radelet, Steven and Jeffrey Sachs (2000), The onset of the East Asian financial crisis, Currency crises, University of Chicago Press, 105-162.

Scheinkman, Jose and Wei Xiong (2003), Overconfidence and speculative bubbles, Journal of Political Economy 111, 1183-1219.

Shiller, Robert, Fumiko Kon-Ya, and Yoshiro Tsutsui (1991), Investor behavior in the October 1987 stock market crash: The case of Japan, Journal of the Japanese and International Economies 5, 1-13.

Sims, Christopher (2003), Implications of rational inattention, Journal of Monetary Economics 50, 665-690. 
Stulz, Rene and Walter Wasserfallen (1995), Foreign equity investment restrictions and shareholder wealth maximization: theory and evidence, Review of Financial Studies 8, 10191057.

Van Nieuwerburgh, Stijn and Laura Veldkamp (2009), Information immobility and the home bias puzzle, Journal of Finance 64, 1187-1215.

Xiong, Wei (2012), Bubbles, crises, and heterogeneous beliefs, Handbook for Systemic Risk, edited by Jean-Pierre Fouque and Joe Langsam, Cambridge University Press. 


\section{Figure 1: Number of Pairs and Average Price Ratio of A Shares to $H$ Shares}

The dotted line with the scale on the right is the number of pairs of $\mathrm{A}$ and $\mathrm{H}$ shares issued by Chinese firms. The solid line with the scale on the left is the average price ratio of A shares and $\mathrm{H}$ shares, weighted across different pairs by the total market value of each pair's $\mathrm{A}$ and $\mathrm{H}$ shares.

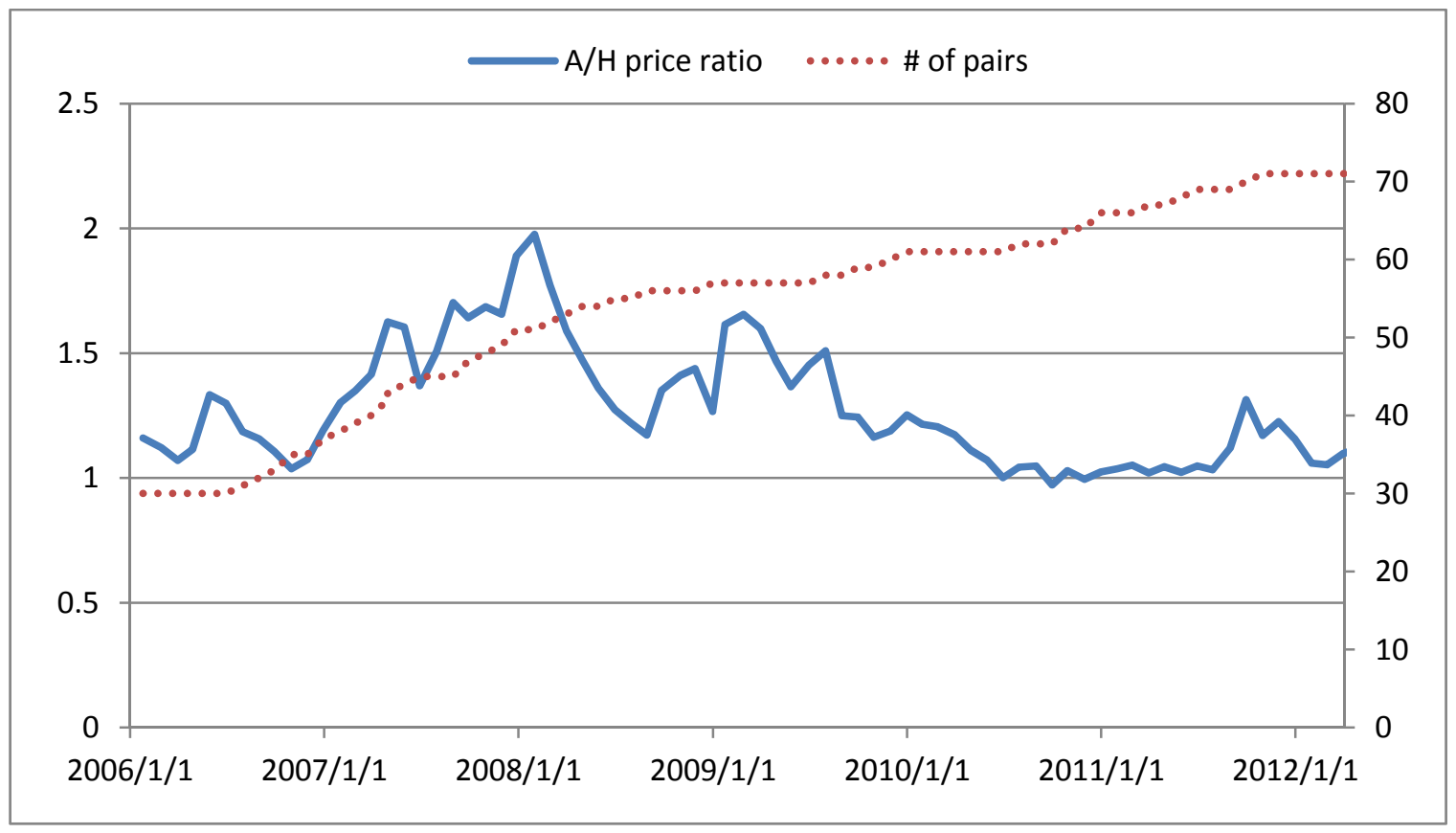


Figure 2: Sample Distribution of Analyst Forecasts across Firms and over Time

In Panel A, each bar indicates the number of forecasts regarding a firm in our sample. In panel B, each bar indicates the number of analyst forecasts made in a month. In both panels, the top part of a bar indicates the number of forecast revisions made by foreign analysts while the bottom part is the number of forecast revisions made by local analysts.

\section{A: Distribution across Firms}

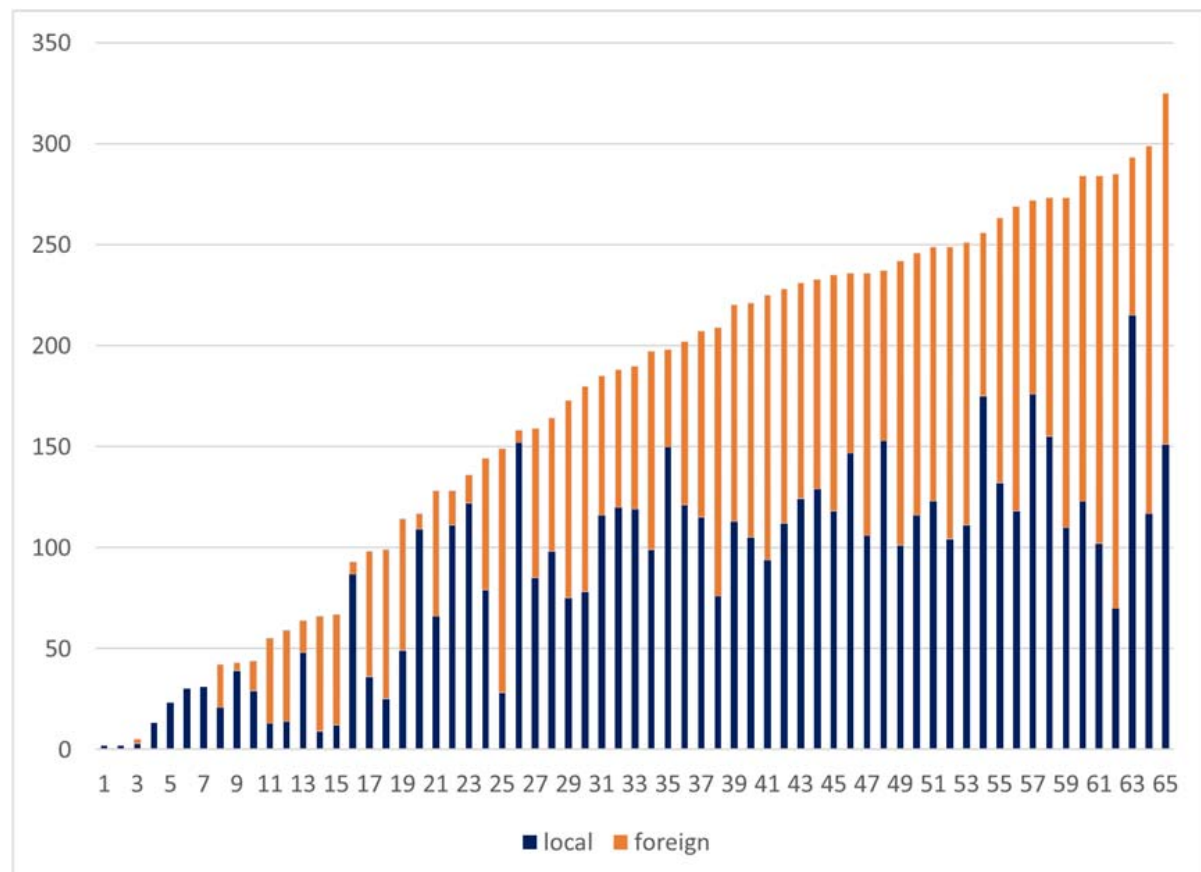

Panel B: Distribution over Time

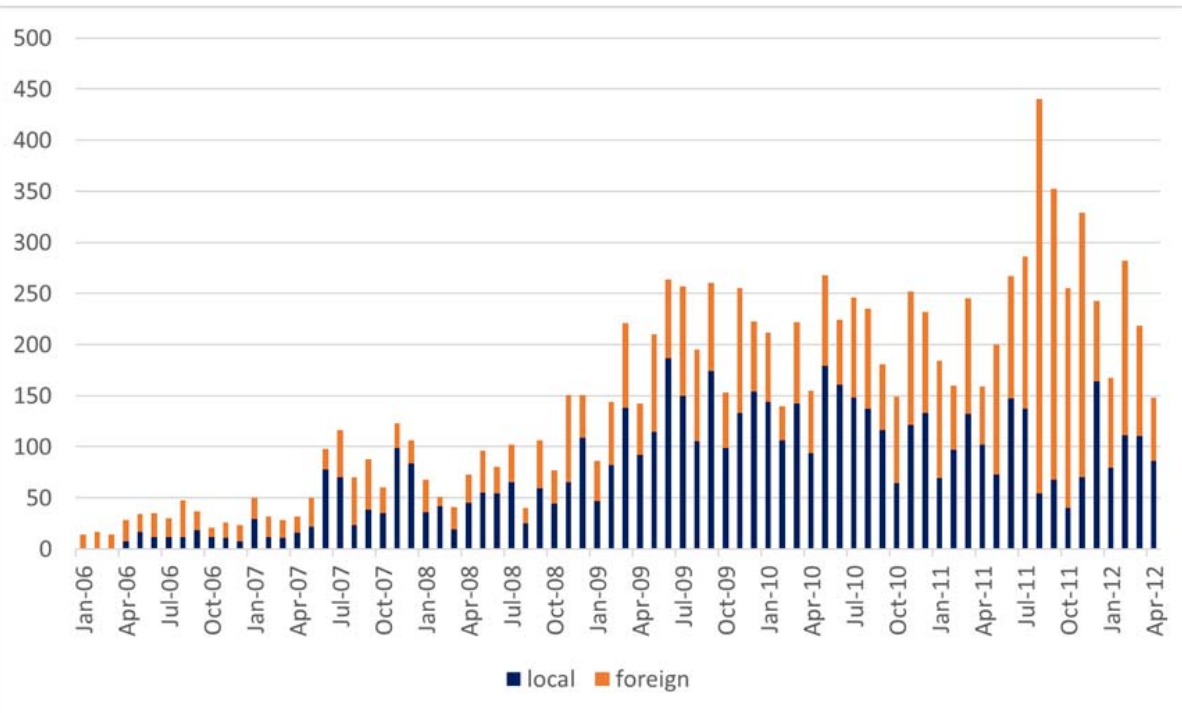


Figure 3: Sample Distribution of Influential Forecasts across Firms

Each bar indicates the number of influential forecast revisions for a firm. The top part of the bar indicates the number of influential forecast revisions made by foreign analysts while the bottom part is the number of influential revisions by local analysts.

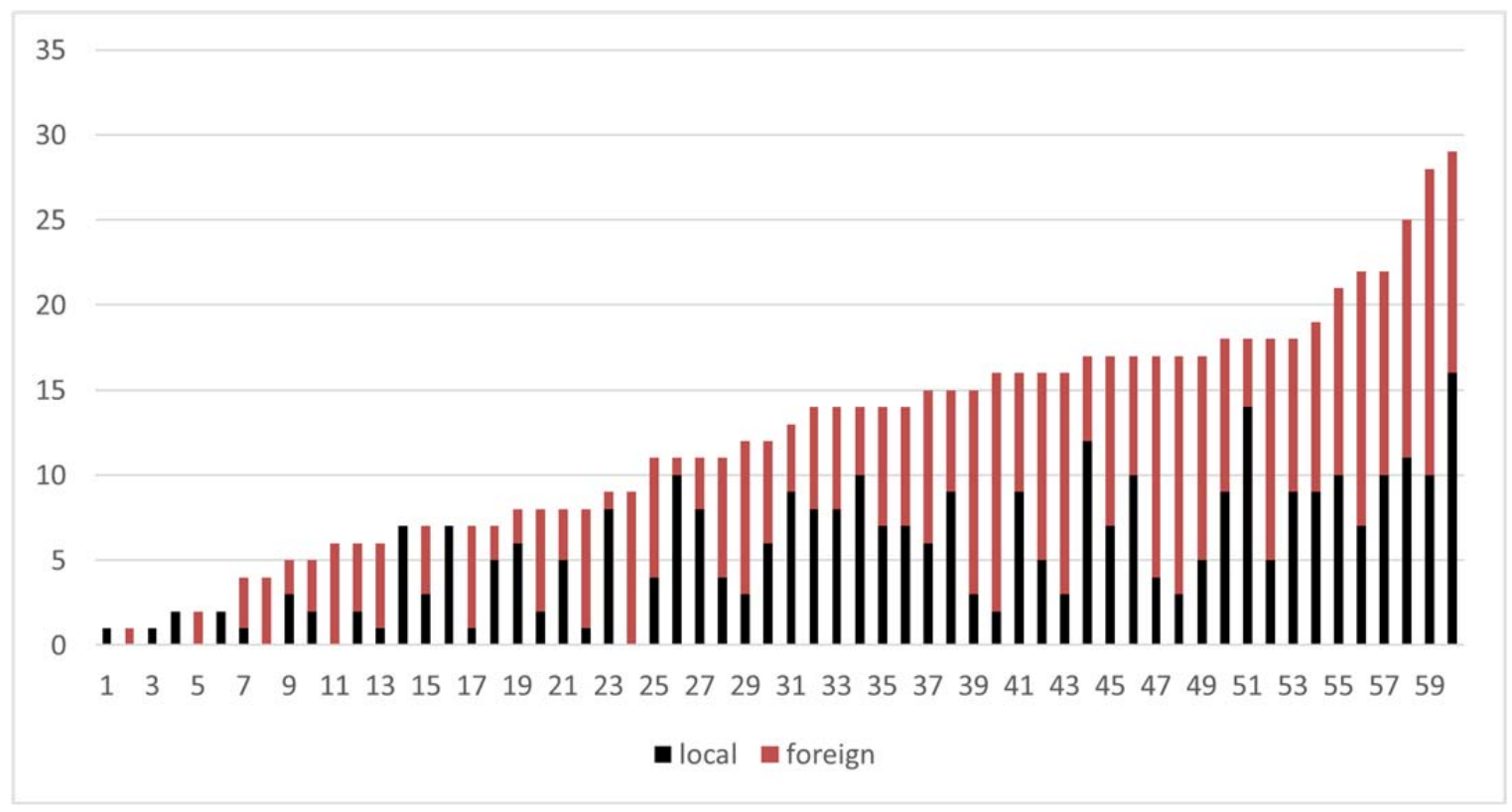




\section{Table 1: Characteristics of Pairs of $A$ and $H$ Shares}

Market Ret for A shares is the daily return of the Shanghai Composite Index, and for H shares is the daily return of the Hong Kong Hang Seng Index. Share Ret is the daily return of either A or $\mathrm{H}$ share of the pairs of A and $\mathrm{H}$ shares in our sample. Ret Vol is each share's daily return volatility. Idiosyn $\mathrm{Vol}$ is each share's idiosyncratic volatility after a linear regression to remove the contemporaneous returns of the Shanghai Composite Index and the Hong Kong Hang Seng Index, and R-Square is the R-square of the regression. Skewness is each share's daily return skewness. Amihud is the illiquidity measure of Amihud (2002) with the unit of $10^{-8}$. Turnover is daily traded shares divided by the total number of tradable shares. Retail is the fraction of all tradable shares held by retail investors at the end of each year. $H$-fraction is the fraction of a firm's tradable $\mathrm{H}$ shares in its total number of tradable shares. $\log (\mathrm{Size})$ is the logarithm of the total market value of a firm's tradable A and $\mathrm{H}$ shares. Correlation is the daily return correlation between a firm's A and $\mathrm{H}$ shares. We use *,**, and *** to denote significance levels of $10 \%$, $5 \%$, and $1 \%$, respectively.

\begin{tabular}{|c|c|c|c|c|c|c|c|c|c|c|c|c|}
\hline \multicolumn{13}{|c|}{ Panel A: Share Characteristics } \\
\hline & \multicolumn{5}{|c|}{ A Shares } & \multicolumn{5}{|c|}{ H Shares } & \multicolumn{2}{|c|}{ A-H } \\
\hline & mean & std & $\min$ & median & $\max$ & mean & Std & $\min$ & median & $\max$ & diff & t-value \\
\hline Market Ret & 0.0004 & 0.019 & -0.088 & 0.001 & 0.095 & 0.0003 & 0.019 & -0.127 & 0.001 & 0.143 & 0.0001 & 0.14 \\
\hline Share Ret & 0.0003 & 0.030 & -0.136 & 0.000 & 0.210 & 0.0005 & 0.035 & -0.371 & 0.000 & 0.675 & -0.0002 & $-1.86^{*}$ \\
\hline Ret Vol & 0.029 & 0.006 & 0.011 & 0.029 & 0.044 & 0.036 & 0.008 & 0.021 & 0.038 & 0.059 & -0.008 & $-11.9 * * *$ \\
\hline Idiosyn Vol & 0.020 & 0.006 & 0.008 & 0.020 & 0.036 & 0.029 & 0.009 & 0.015 & 0.030 & 0.054 & -0.009 & $-12.8^{* * *}$ \\
\hline R-Square & 0.501 & 0.120 & 0.193 & 0.514 & 0.783 & 0.412 & 0.185 & 0.066 & 0.391 & 0.815 & 0.089 & $5.81^{* * *}$ \\
\hline Skewness & 0.116 & 0.246 & -0.617 & 0.079 & 1.173 & 0.664 & 0.520 & -0.339 & 0.600 & 2.892 & -0.548 & $-8.19 * * *$ \\
\hline Amihud & 0.040 & 0.058 & 0.002 & 0.019 & 0.323 & 0.885 & 2.952 & 0.001 & 0.043 & 21.559 & -0.845 & $-2.44 * * *$ \\
\hline Turnover & 2.264 & 1.622 & 0.598 & 1.838 & 10.297 & 0.754 & 0.357 & 0.149 & 0.689 & 1.768 & 1.511 & $7.52 * * *$ \\
\hline Retail & 0.567 & 0.281 & 0.018 & 0.586 & 0.999 & 0.580 & 0.232 & 0.001 & 0.580 & 0.998 & -0.012 & -0.7 \\
\hline
\end{tabular}




\begin{tabular}{lccccc}
\hline \multicolumn{6}{c}{ Panel B: Firm Characteristic } \\
\hline & mean & std & min & median & $\max$ \\
\cline { 2 - 6 } H-fraction & 0.513 & 0.168 & 0.154 & 0.495 & 0.962 \\
Log(Size) & 23.932 & 1.676 & 20.946 & 23.919 & 27.850 \\
Correlation & 0.444 & 0.086 & 0.163 & 0.452 & 0.663 \\
\hline
\end{tabular}

\begin{tabular}{cccc}
\hline \multicolumn{4}{c}{ Panel C: Granger Causality of A/H market } \\
\hline & H leads A & H does not lead A & Subtotal \\
\hline A leads H & 10 & 11 & 21 \\
A does not lead H & 14 & 36 & 50 \\
subtotal & 24 & 47 & 71 \\
\hline
\end{tabular}




\section{Table 2: Difference in Earnings Accounting in $\mathrm{A}$ and $\mathrm{H}$ Markets}

Diff is the absolute difference of EPS between A and H markets, $n$ is the sample size, Diff_rel is the absolute difference of EPS between A and $\mathrm{H}$ markets deflated by the previous-year-end $\mathrm{H}$-market stock price, daeps is the absolute value of year-to-year change of A-market EPS, dheps is the absolute value of year-to-year change of H-market EPS, ddeps is the absolute value of difference between daeps and dheps, corr is the correlation between daeps and dheps,

\begin{tabular}{|c|c|c|c|c|c|c|c|}
\hline \multicolumn{8}{|c|}{ Panel A: difference } \\
\hline variable & $\mathrm{n}$ & mean & $\min$ & p75 & p90 & p99 & $\max$ \\
\hline diff & 245 & 0.005 & 0.000 & 0.001 & 0.010 & 0.090 & 0.148 \\
\hline diff_rel & 245 & 0.001 & 0.000 & 0.000 & 0.002 & 0.020 & 0.052 \\
\hline daeps & 192 & 0.318 & 0.003 & 0.395 & 0.765 & 3.166 & 3.200 \\
\hline dheps & 196 & 0.316 & 0.000 & 0.384 & 0.780 & 3.166 & 3.200 \\
\hline ddeps & 192 & 0.006 & 0.000 & 0.002 & 0.013 & 0.090 & 0.148 \\
\hline \multicolumn{8}{|c|}{ Panel B: correlation } \\
\hline corr & & & & 0.999 & & & \\
\hline
\end{tabular}




\section{Table 3: Price Reactions to Earnings Announcement}

$C A R(-1,1)$ is the cumulative abnormal return from one day before to one day after the earnings announcement. $C A R(-1,2)$ is the cumulative abnormal return from one day before to two days after the announcement. $C A R(-1,3)$ is the cumulative abnormal return from one day before to three days after the announcement. We estimate a linear regression of the daily return of each share on the returns of the Shanghai Composite Index and the Hong Kong Hang Seng Index from 365 days before to 10 days before each announcement and then use the estimated regression coefficients to compute the share's abnormal returns across the announcement. Surprise is measured by the difference between reported EPS and the consensus forecast before the announcement, further deflated by the Hshare price ten days before the announcement. $\log ($ Size $)$ is the logarithm of the market capitalization of one type of tradable shares (A or $\mathrm{H}$ ) of each firm at the end of the previous year. Lev is the firm's leverage. In Panel B, the dependent variable of the regression is $|C A R(-1,1)|$. We use *, **, and *** to denote significance levels of $10 \%, 5 \%$, and $1 \%$, respectively.

\begin{tabular}{|c|c|c|c|c|c|c|c|}
\hline \multicolumn{8}{|c|}{ Panel A: Summary of Price Reactions } \\
\hline & & \multicolumn{2}{|c|}{ A Shares } & \multicolumn{2}{|c|}{ H Shares } & \multicolumn{2}{|c|}{$\mathrm{A}-\mathrm{H}$} \\
\hline & nobs & mean & t-value & Mean & t-value & mean & t-value \\
\hline$|C A R(-1,1)|$ & 249 & 0.028 & $14.93 * * *$ & 0.041 & $17.50^{* * *}$ & -0.013 & $-5.24 * * *$ \\
\hline$|C A R(-1,2)|$ & 216 & 0.034 & $14.28 * * *$ & 0.046 & $16.78^{* * *}$ & -0.012 & $-3.86 * * *$ \\
\hline$|C A R(-1,3)|$ & 194 & 0.040 & $13.92^{* * *}$ & 0.053 & $16.19 * * *$ & -0.013 & $-3.68^{* * *}$ \\
\hline
\end{tabular}

\begin{tabular}{|c|c|c|c|c|}
\hline \multicolumn{5}{|c|}{ Panel B: Regression } \\
\hline & \multicolumn{2}{|c|}{ Model 1} & \multicolumn{2}{|c|}{ Model 2} \\
\hline & estimator & t-value & estimator & t-value \\
\hline$H$ & 0.011 & $4.77 * * *$ & 0.012 & $4.42 * * *$ \\
\hline |Surprise| & -0.035 & $-1.96^{*}$ & & \\
\hline$H \cdot \mid$ Surprise $\mid$ & 0.071 & $3.50^{* * *}$ & 0.081 & $1.79 *$ \\
\hline $\log ($ Size $)$ & -0.004 & $-3.03 * * *$ & 0.002 & 0.81 \\
\hline Lev & 0.002 & 0.33 & & \\
\hline EA effect & \multicolumn{2}{|c|}{ No } & \multicolumn{2}{|c|}{ Yes } \\
\hline F-value & \multicolumn{2}{|c|}{$9.23^{* * *}$} & \multicolumn{2}{|c|}{$10.31 * * *$} \\
\hline R-Square & \multicolumn{2}{|c|}{0.080} & \multicolumn{2}{|c|}{0.112} \\
\hline
\end{tabular}




\section{Table 4: Number of Influential Forecasts}

In Panel A, we define a forecast revision to be influential if the share's $C A R(-1,1)$ has the same sign as the direction of the news and an absolute value greater than a $2.5 \%$ tail of normal distribution with volatility equal to the share's idiosyncratic volatility during the prior year. Numbers in parenthesis for A and $\mathrm{H}$ shares are the t-statistics for testing the percentage being equal to $2.5 \%$. Numbers in parenthesis for the (A-H) column are t-statistics for testing the percentage of $\mathrm{A}$ shares being equal to that of $\mathrm{H}$ shares. Local houses are brokerage firms or research firms incorporated in mainland China with Chinese corporations as their controlling shareholders. Foreign houses are brokerage firms or research firms incorporated outside Mainland China without Chinese corporations as their controlling shareholders. In Panel B, we define a forecast revision to be influential by requiring a $0.5 \%$ tail of normal distribution to cut off the absolute value of a share's $C A R(-1,1)$. We use $*$, **, and *** to denote significance levels of $10 \%, 5 \%$, and $1 \%$, respectively.

\begin{tabular}{|c|c|c|c|c|c|c|}
\hline & \multirow[t]{2}{*}{ Nobs } & \multicolumn{2}{|c|}{ \# of Influential Forecasts } & \multicolumn{3}{|c|}{ Percentage of Influential Forecast } \\
\hline & & A Shares & H Shares & A Shares & H Shares & $\mathrm{A}-\mathrm{H}$ \\
\hline \multicolumn{7}{|c|}{ Panel A: 2.5\% Tail Distribution } \\
\hline \multirow[t]{2}{*}{ Foreign Houses } & 5272 & 165 & 270 & $3.13 \%$ & $5.12 \%$ & $-1.99 \%$ \\
\hline & & & & $(2.63)^{* * *}$ & $(8.63)^{* * *}$ & $(-5.54)^{* * *}$ \\
\hline \multirow[t]{2}{*}{ Local Houses } & 5805 & 208 & 155 & $3.58 \%$ & $2.67 \%$ & $0.91 \%$ \\
\hline & & & & $(4.44)^{* * *}$ & $(0.80)$ & $(3.06)^{* * *}$ \\
\hline \multicolumn{7}{|c|}{ Panel B: 0.5\% Tail Distribution } \\
\hline \multirow[t]{2}{*}{ Foreign Houses } & 5272 & 75 & 140 & $1.42 \%$ & $2.66 \%$ & $-1.24 \%$ \\
\hline & & & & $(5.66)^{* * *}$ & $(9.73)^{* * *}$ & $(-4.62)^{* * *}$ \\
\hline \multirow[t]{2}{*}{ Local Houses } & 5805 & 103 & 71 & $1.77 \%$ & $1.22 \%$ & $0.55 \%$ \\
\hline & & & & $(7.35)^{* * *}$ & $(5.01)^{* * *}$ & $(2.60)^{* * *}$ \\
\hline
\end{tabular}




\section{Table 5: Summary Statistics for Variables Used in Analyzing Forecast Revisions}

Experience is measured as the number of quarters an analyst has covered the firm up to the time of the event minus the average number of quarters all analysts have covered the firm. Accuracy is the quintile derived from sorting the analyst's previous year's forecast errors among errors of all forecast observations. Boldness $=1$ if the new forecast deviates further away from the consensus than the analyst's previous forecast. Dispersion is the dispersion of updated forecasts of all analysts before the current event. $B M$ is the book-value to market-value ratio at the end of the previous year. Coverage is the number of analysts covering the firm. Retail is the fraction of all tradable shares held by retail investors. Size is the market value of all tradable shares at the end of the previous year. Turnover, Volatility, and Momentum are all measured based on the averages of the prior one-week period. Variables that are marked by a subscript of either $a$ or $h$ are separately measured for A and $\mathrm{H}$ shares of the firm.

\begin{tabular}{cccccccc}
\hline variables & mean & std & Min & p1 & median & p99 & max \\
\hline Experience & 0.540 & 5.495 & -12.825 & -12.825 & 0.679 & 11.448 & 11.448 \\
Accuracy & 2.098 & 1.366 & 0 & 0 & 2 & 4 & 4 \\
Boldness & 0.331 & 0.471 & 0 & 0 & 0 & 1 & 1 \\
Dispersion & 0.232 & 0.592 & -1.983 & -1.983 & 0.123 & 3.776 & 3.776 \\
Log(BM) & -1.376 & 0.588 & -3.170 & -3.170 & -1.301 & -0.110 & -0.110 \\
Coverage & 17.507 & 9.014 & 1 & 2 & 17 & 42 & 46 \\
Log(size)_a & 23.885 & 1.592 & 20.472 & 20.472 & 23.823 & 27.926 & 27.926 \\
Log(size)_h & 23.647 & 1.623 & 20.084 & 20.084 & 23.391 & 27.896 & 27.896 \\
Log(turnover)_a & -0.386 & 1.411 & -4.443 & -4.443 & -0.214 & 2.136 & 2.136 \\
Log(turnover)_h & -0.544 & 0.770 & -2.522 & -2.522 & -0.519 & 1.246 & 1.246 \\
Log(volatility)_a & -4.008 & 0.642 & -5.805 & -5.805 & -3.972 & -2.670 & -2.670 \\
Log(volatility)_h & -3.845 & 0.656 & -5.616 & -5.616 & -3.818 & -2.354 & -2.354 \\
Momentum_a & 0.000 & 0.013 & -0.036 & -0.036 & 0.000 & 0.039 & 0.039 \\
Momentum_h & 0.000 & 0.016 & -0.045 & -0.045 & 0.000 & 0.052 & 0.052 \\
Retail_a & 0.510 & 0.280 & 0.027 & 0.027 & 0.538 & 0.973 & 0.973 \\
Retail_h & 0.541 & 0.222 & 0.001 & 0.001 & 0.550 & 0.965 & 0.965 \\
\hline
\end{tabular}


Table 6: Logit Regression Analysis of Price Reactions to Analyst Forecast Revisions

The dependent variable is a dummy for whether a forecast is influential. Local houses are brokerage or research firms incorporated in mainland China with Chinese corporations as controlling shareholders. Foreign houses are brokerage or research firms incorporated outside mainland China without Chinese corporations as controlling shareholders. We define a forecast revision to be influential if the share's CAR(-1,1) has the same sign as the direction of the news and an absolute value greater than a $2.5 \%$ tail of normal distribution with volatility equal to the share's idiosyncratic volatility during the prior one year. $H=1$ if the observation is for $\mathrm{H}$ shares. Experience is measured as the number of quarters an analyst has covered the firm up to the time of the event minus the average number of quarters all analysts have covered the firm. Accuracy is the quintile derived from sorting the analyst's previous forecast errors among errors of all forecast observations. Boldness $=1$ if the new forecast deviates further away from the consensus than the analyst's previous forecast. Dispersion is the dispersion of updated forecasts of all analysts before the current event. BM is the book-value to market-value ratio at the end of the previous year. Coverage is the number of analysts covering the firm. Retail is the fraction of all tradable shares held by retail investors. Size is the market value of all tradable shares at the end of the previous year. Turnover, Volatility, and Momentum are all measured based on the averages of the prior one-week period. We use *, **, and *** to denote significance levels of $10 \%, 5 \%$, and $1 \%$, respectively, based on standard errors clustered in firm/analyst pairs.

\begin{tabular}{|c|c|c|c|c|c|c|c|c|}
\hline & \multicolumn{4}{|c|}{ Local Houses } & \multicolumn{4}{|c|}{ Foreign Houses } \\
\hline & \multicolumn{2}{|c|}{ Model 1} & \multicolumn{2}{|c|}{ Model 2} & \multicolumn{2}{|c|}{ Model 1} & \multicolumn{2}{|c|}{ Model 2} \\
\hline & estimator & t-value & estimator & t-value & estimator & t-value & estimator & t-value \\
\hline$H$ & -0.304 & $-2.99 * * *$ & -0.303 & $-1.99 * *$ & 0.513 & $4.34 * * *$ & 0.224 & $1.74 *$ \\
\hline Experience & & & -0.012 & -0.76 & & & -0.010 & -0.87 \\
\hline Accuracy & & & -0.090 & -1.44 & & & -0.023 & -0.41 \\
\hline Inf_lag & & & 0.102 & 0.51 & & & 0.235 & 1.43 \\
\hline Bondness & & & 0.038 & 0.25 & & & 0.095 & 0.61 \\
\hline Dispersion & & & -0.019 & -0.17 & & & -0.040 & -0.47 \\
\hline $\log (B M)$ & & & -0.104 & -1.02 & & & 0.153 & 1.45 \\
\hline Coverage & & & -0.007 & -0.72 & & & -0.021 & $-2.24 * *$ \\
\hline Retail & & & 0.803 & $2.49 * * *$ & & & 0.914 & $3.69 * * *$ \\
\hline $\log ($ size $)$ & & & 0.154 & $2.27 * *$ & & & 0.195 & $3.06 * * *$ \\
\hline Log(turnover) & & & 0.053 & 0.50 & & & 0.094 & 1.27 \\
\hline Log(volatility) & & & 0.679 & $4.01 * * *$ & & & 0.956 & $7.12^{* * *}$ \\
\hline Momentum & & & 24.780 & $4.17^{* * *}$ & & & 21.157 & $5.99 * * *$ \\
\hline Nobs & \multicolumn{2}{|c|}{5805} & \multicolumn{2}{|c|}{3501} & \multicolumn{2}{|c|}{5272} & \multicolumn{2}{|c|}{3600} \\
\hline Chi2 & \multicolumn{2}{|c|}{$8.96^{* * *}$} & \multicolumn{2}{|c|}{$105.08^{* * *}$} & \multicolumn{2}{|c|}{$18.85^{* * *}$} & \multicolumn{2}{|c|}{$211.79 * * *$} \\
\hline Pseudo-R2 & \multicolumn{2}{|c|}{0.003} & \multicolumn{2}{|c|}{0.053} & \multicolumn{2}{|c|}{0.004} & \multicolumn{2}{|c|}{0.082} \\
\hline
\end{tabular}




\section{Table 7: Logit Regression Analysis of Price Reactions to Forecasts by Chinese and Non-Chinese Analysts of Foreign Houses}

The dependent variable is a dummy for whether a forecast is influential. The sample includes forecasts made by foreign houses that hire both Chinese and nonChinese analysts. Experience is measured as the number of quarters an analyst has covered the firm up to the time of the event minus the average number of quarters all analysts have covered the firm. Accuracy is the quintile derived from sorting the analyst's previous forecast errors among errors of all forecast observations. Boldness $=1$ if the new forecast deviates further away from the consensus than the analyst's previous forecast. Dispersion is the dispersion of updated forecasts of all analysts before the current event. $B M$ is the book-value to market-value ratio at the end of the previous year. Coverage is the number of analysts covering the firm. Retail is the fraction of all tradable shares held by retail investors. Size is the market value of all tradable shares at the end of the previous year. Turnover, Volatility, and Momentum are all measured based on the averages of the prior one-week period. The third major column reports the coefficients of all interaction terms with the NonChineseAnalyst dummy in regression (3). We use *, **, and *** to denote significance levels of $10 \%$, $5 \%$, and $1 \%$, respectively, based on standard errors clustered in firm/analyst pairs.

\begin{tabular}{|c|c|c|c|c|c|c|}
\hline & \multicolumn{2}{|c|}{ Non-Chinese Analysts } & \multicolumn{2}{|c|}{ Chinese Analysts } & \multicolumn{2}{|c|}{ Difference } \\
\hline & estimator & t-value & estimator & t-value & parameter & t-value \\
\hline$H$ & 0.671 & $2.80 * * *$ & 0.049 & 0.24 & 0.623 & $1.99 * *$ \\
\hline Experience & -0.004 & -0.15 & 0.024 & 1.11 & -0.028 & -0.81 \\
\hline Accuracy & -0.068 & -0.82 & 0.082 & 0.92 & -0.150 & -1.23 \\
\hline Inf_lag & 0.329 & 1.08 & 0.075 & 0.31 & 0.255 & 0.66 \\
\hline Bondness & 0.035 & 0.13 & 0.276 & 1.06 & -0.240 & -0.65 \\
\hline Dispersion & -0.086 & -0.51 & 0.010 & 0.09 & -0.095 & -0.48 \\
\hline $\log (B M)$ & -0.468 & $-2.07 * *$ & 0.401 & $2.06^{* *}$ & -0.868 & $-2.91 * * *$ \\
\hline Coverage & 0.004 & 0.24 & -0.038 & $-2.72 * * *$ & 0.042 & $1.90 *$ \\
\hline Retail & 0.274 & 0.63 & 0.836 & $2.00 * *$ & -0.562 & -0.93 \\
\hline $\log (\operatorname{size})$ & 0.357 & $2.68 * * *$ & 0.038 & 0.46 & 0.319 & $2.03 * *$ \\
\hline Log(turnover) & -0.023 & -0.14 & 0.337 & $3.49 * * *$ & -0.360 & $-1.94^{*}$ \\
\hline Log(volatility) & 1.054 & $4.91 * * *$ & 0.961 & $4.78 * * *$ & 0.093 & 0.32 \\
\hline Momentum & 19.065 & $2.51^{* * *}$ & 19.237 & $4.72 * * *$ & -0.172 & -0.02 \\
\hline Nobs & \multicolumn{2}{|c|}{1205} & \multicolumn{2}{|c|}{1435} & \multicolumn{2}{|c|}{2640} \\
\hline Chi2 & \multicolumn{2}{|c|}{$174.43^{* * *}$} & \multicolumn{2}{|c|}{$145.76^{* * *}$} & \multicolumn{2}{|c|}{$320.40^{* * *}$} \\
\hline Pseudo-R2 & \multicolumn{2}{|c|}{0.108} & \multicolumn{2}{|c|}{0.131} & \multicolumn{2}{|c|}{0.123} \\
\hline
\end{tabular}




\section{Table 8: Logit Regression Analysis of Price Reactions to Forecasts by Locally and Foreign-Educated Analysts of Local Houses}

The dependent variable is a dummy for whether a forecast is influential. The sample includes forecasts made by analysts in local houses with educational information. Experience is measured as the number of quarters an analyst has covered the firm up to the time of the event minus the average number of quarters all analysts have covered the firm. Accuracy is the quintile derived from sorting the analyst's previous forecast errors among errors of all forecast observations. Boldness $=1$ if the new forecast deviates further away from the consensus than the analyst's previous forecast. Dispersion is the dispersion of updated forecasts of all analysts before the current event. $B M$ is the book-value to market-value ratio at the end of the previous year. Coverage is the number of analysts covering the firm. Retail is the fraction of all tradable shares held by retail investors. Size is the market value of all tradable shares at the end of the previous year. Turnover, Volatility, and Momentum are all measured based on the averages of the prior one-week period. The third major column reports only the coefficients of all interaction terms with Locally-Educated dummy in regression (4). We use *,**, and ***to denote significance levels of $10 \%$, $5 \%$, and $1 \%$, respectively, based on standard errors clustered in firm/analyst pairs.

\begin{tabular}{|c|c|c|c|c|c|c|}
\hline & \multicolumn{2}{|c|}{ Locally Educated Analysts } & \multicolumn{2}{|c|}{ Foreign-Educated Analysts } & \multicolumn{2}{|c|}{ Difference } \\
\hline & estimator & $\mathrm{t}$-value & estimator & $\mathrm{t}$-value & parameter & t-value \\
\hline$H$ & -0.682 & $-2.53 * *$ & 0.423 & 0.71 & -1.106 & $-1.69 *$ \\
\hline Experience & 0.027 & 0.99 & -0.138 & $-3.45 * * *$ & -0.165 & $-3.40 * * *$ \\
\hline Accuracy & -0.282 & $-2.74 * * *$ & 0.126 & 0.87 & -0.408 & $-2.31 * *$ \\
\hline Inf_lag & -0.755 & $-1.76^{*}$ & 0.490 & 0.85 & -1.245 & $-1.74^{*}$ \\
\hline Bondness & 0.381 & 1.46 & 0.157 & 0.50 & 0.225 & 0.55 \\
\hline Dispersion & -0.213 & -0.61 & -0.761 & $-3.75 * * *$ & 0.548 & 1.36 \\
\hline $\log (B M)$ & -0.137 & -0.72 & -0.273 & -0.89 & 0.136 & 0.38 \\
\hline Coverage & 0.003 & 0.18 & -0.029 & -0.92 & 0.031 & 0.91 \\
\hline Retail & 0.903 & $2.08 * *$ & 0.216 & 0.20 & 0.687 & 0.60 \\
\hline $\log ($ size $)$ & 0.110 & 0.91 & 0.121 & 0.56 & -0.011 & -0.04 \\
\hline Log(turnover) & -0.175 & -1.10 & 0.248 & 1.04 & -0.423 & -1.49 \\
\hline Log(volatility) & 1.041 & $4.01^{* * *}$ & -0.476 & $-2.26 * * *$ & 1.517 & $4.54 * * *$ \\
\hline Momentum & 35.231 & $3.76 * * *$ & 39.225 & $2.59 * * *$ & -3.993 & -0.22 \\
\hline Nobs & \multicolumn{2}{|c|}{1053} & \multicolumn{2}{|c|}{501} & \multicolumn{2}{|c|}{1554} \\
\hline Chi2 & \multicolumn{2}{|c|}{$73.07 * * *$} & \multicolumn{2}{|c|}{$85.51^{* * *}$} & \multicolumn{2}{|c|}{$160.73^{* * *}$} \\
\hline Pseudo-R2 & \multicolumn{2}{|c|}{0.113} & \multicolumn{2}{|c|}{0.095} & \multicolumn{2}{|c|}{0.112} \\
\hline
\end{tabular}




\section{Table 9: Comparing Forecast Accuracy of Analysts of Local and Foreign Houses}

The dependent variable in Model 1 and 2 is the absolute forecast error standardized by the previous year-end share price, and the dependent variable in Model 3 and 4 is the rank (from 0 to 9) of the absolute forecast error within each firm/year. Local = 1 if the forecast is made by a local house. $D$ is the number of days between the forecast announcement and the actual EPS announcement. Firm/year Fx is firm/year fixed effect, i.e., a dummy for every firm/year pair. Panel A is for the full sample, Panel B is for the forecasts made by foreign houses, and Panel C is for the forecasts made by China houses. We use *, **, and *** to denote significance levels of 10\%, 5\%, and 1\%, respectively. The standard deviation for t-value in Model 1 and Model 3 are clustered in firm/analyst pairs.

\begin{tabular}{|c|c|c|c|c|c|c|c|c|}
\hline & \multicolumn{2}{|c|}{ Model 1: derr } & \multicolumn{2}{|c|}{ Model 2: derr } & \multicolumn{2}{|c|}{ Model 3: accrank } & \multicolumn{2}{|c|}{ Model 4: accrank } \\
\hline & Parameter & t-value & Parameter & t-value & Parameter & t-value & Parameter & t-value \\
\hline \multicolumn{9}{|c|}{ Panel A: Full Sample } \\
\hline Local & 0.0005 & 0.25 & 0.0001 & 0.22 & 0.0064 & 0.08 & 0.0559 & 0.96 \\
\hline$D$ & 0.00007 & $12.96 * * *$ & 0.00007 & $26.42 * * *$ & 0.0097 & $24.48 * * *$ & 0.0104 & $39.48 * * *$ \\
\hline Firm/year Fx & \multicolumn{6}{|c|}{ controlled } & \multicolumn{2}{|c|}{ Controlled } \\
\hline Nobs & \multicolumn{2}{|c|}{10127} & \multicolumn{2}{|c|}{10127} & \multicolumn{2}{|c|}{10127} & \multicolumn{2}{|c|}{10127} \\
\hline$R$-square & \multicolumn{2}{|c|}{0.041} & \multicolumn{2}{|c|}{0.119} & \multicolumn{2}{|c|}{0.128} & \multicolumn{2}{|c|}{0.137} \\
\hline \multicolumn{9}{|c|}{ Panel B: Foreign House Sample } \\
\hline ChineseAnalyst & -0.0026 & -0.58 & -0.0021 & $-3.26 * * *$ & -0.3639 & $-2.33 * *$ & -0.4599 & $-4.48 * * *$ \\
\hline$D$ & 0.00006 & $5.15^{* * *}$ & 0.00006 & $19.28 * * *$ & 0.0089 & $10.61^{* * *}$ & 0.0094 & $19.43^{* * *}$ \\
\hline Firm/year Fx & \multicolumn{6}{|c|}{ Controlled } & \multicolumn{2}{|c|}{ controlled } \\
\hline Nobs & \multicolumn{2}{|c|}{3422} & \multicolumn{2}{|c|}{3422} & \multicolumn{2}{|c|}{3422} & \multicolumn{2}{|c|}{3422} \\
\hline$R$-square & \multicolumn{2}{|c|}{0.028} & \multicolumn{2}{|c|}{0.106} & \multicolumn{2}{|c|}{0.103} & \multicolumn{2}{|c|}{0.110} \\
\hline \multicolumn{9}{|c|}{ Panel C: Local House Sample } \\
\hline ChinaEdu & 0.0014 & 0.60 & -0.0011 & $-1.87^{*}$ & -0.0571 & -0.44 & 0.0452 & 0.47 \\
\hline$D$ & 0.00006 & $8.32 * * *$ & 0.00005 & $19.88 * * *$ & 0.0092 & $14.42^{* * *}$ & 0.0097 & $21.80 * * *$ \\
\hline Firm/year Fx & \multicolumn{6}{|c|}{ controlled } & \multicolumn{2}{|c|}{ controlled } \\
\hline Nobs & \multicolumn{2}{|c|}{3831} & \multicolumn{2}{|c|}{3831} & \multicolumn{2}{|c|}{3831} & \multicolumn{2}{|c|}{3831} \\
\hline$R$-square & \multicolumn{2}{|c|}{0.043} & \multicolumn{2}{|c|}{0.100} & & & & \\
\hline
\end{tabular}

